\title{
Use of fauna in the traditional medicine of native Toba (qom) from the Argentine Gran Chaco region: an ethnozoological and conservationist approach
}

\author{
Gustavo J. Martínez \\ Equipo de Etnobiología - IDACOR (Conicet) / Museo de Antropología. Universidad Nacional de \\ Córdoba. Hipólito Yrigoyen 174. 5000 Córdoba, República Argentina. \\ Corresponding author \\ \E-mail adress: gustmart@yahoo.com
}

Ethnobiology and Conservation 2013, 2: 2 (20 May 2013)

ISSN 2238-4782

doi: 10.15451/ec2013-8-2.2-1-43

ethnobioconservation.com

\section{Abstract}

The Gran Chaco region is an area of vast cultural and biological richness that is inhabited by different American indigenous hunter-gatherer groups and has a great number of threatened wildlife species. An ethnozoological investigation was carried out to study the medicinal uses of fauna by the Toba (qom) communities of Central Chaco in the surroundings of the Bermejito River. Qualitative, quantitative and participative methods were used alternately to document and characterize the knowledge, significance and role of animals from the Chaco forest within the Toba cultural and medical context. A total of 199 uses corresponding to 72 species belonging to 52 families were documented as part of the animal pharmacopoeia employed by the natives. Information obtained by open and semistructured interviews was used to develop an Index of Local Conservation Priorities (ILCP) that allowed ordering the species according to their Relative Importance, Ecological and Cultural Value, and Conservation Status. Our results showed that of the wide range of species used in Toba zootherapy, a substantial number of reptiles, mammals and birds are included in lists of threatened species for Argentina. The ethnozoological perspective of this study provides an integral view of social and ecological elements that are useful for the protection and/or sustainable management of native species on a regional scale.

Keywords: Animal remedies - Ethnozoology - Tobas - Gran Chaco 
Martínez 2013. Use of fauna in the traditional medicine of native Toba (qom) from the Argentine Gran Chaco region: an ethnozoological and conservational approach. Ethnobio Conserv 2:2

\section{Introduction}

The planetarian biodiversity crisis had highlighted the valuable contribution that ethnobiological studies could make to conservation biology, thus generating support for conservation efforts (Alves 2012; Anderson et al. 2011). In particular over the last decades several studies have considered that the interdisciplinary perspective of ethnozoology is appropriate for determining ecological, sociocultural and human aspects related to animal conservation and management, since it provides a better comprehension about the roles played by animals in a specific cultural context, a crucial tool with potential application to solve problems of wildlifehuman conflict (Alves and Rosa 2006, 2007a,b; Alves et al. 2008, 2010; Alves and Alves 2011; Alves 2012). Most of these studies involve regions with rich biodiversity, where indigenous groups and/or peasants make a conspicuous use of the fauna as sources of food, folk medicine, or other materials, or for symbolical aspects of their lives (Alves 2012; Arenas 2003; Arenas and Porini 2009; Bourdy et al. 2004; MonroyVilchis et al. 2008). The study of zootherapy is particularly revealing due to the number of species and applications involved, and it is characterized by a wide geographical distribution and a remote historical origin (Alves and Alves 2011; CostaNeto 1999).

In Latin America, many cultures still resort to animal-derived remedies as part of their traditional medicine practices, most of them deeply rooted in a long-standing tradition of wild fauna use, including many endangered species, to treat all kinds of diseases. This is evidenced, for example, by the use of about 95 animal species in folk medicine in the state of Bahia (Costa-Neto 2011), 36 species in the semiarid region of Pernambuco (Alves et al. 2009) and 51 species in the Caatinga Biome in the state of Paraiba (Alves et al. 2011), in Brazil. In México the use of 18 species in Mapimi, Durango (Jacobo-Salcedo et al. 2010), 24 species in San Luis Potosí (Alonso-Castro et al. 2011), and 74 species in the state of Chiapas (Enriquez Vazquez et al. 2006) were also reported. Finally, and just to conclude the mention of some of Latin American mostly studied, 14 species for selling were documented in the Bolivian rain forest (Apaza et al. 2003) and more than 20 species used by the Izoceño-Gurani from the South East Bolivia (Bourdy et al. 2004). Reviews including wider geographical areas estimate the use of around 42 species of insects (CostaNeto 2002) and 250 animals (Alves 2009) in the NE Brazil, as well as 354 animals species all over Brazil (Alves et al. 2013 ) and at least 584 animal species in the whole Latin America (Alves and Alves 2011). Despite this, those studies underline the need for further research into zootherapeutic practices in the latter region, particularly because medicinal use of fauna represents an additional pressure for many species since many are highly promising in the search for new natural products of pharmaceutical interest (Alves and Albuquerque 2012; Dossey 2010). In this sense, recent discussion regarding the relationship between traditional medicine and biodiversity in Latin America has evidenced an increasing use, commercialization and unsustainable exploitation of animals due to new demands for natural medicine, rising the pressure on wild species, especially those endangered (Alves et al. 2007, 2008, 2009, 2011; Alves and Alves 2011).

In contrast with the broad range of studies on traditional medicinal animals in Brazil, other countries from South America such as Argentina, sharing Gran Chaco region with Brazil, have not published visible articles of medical ethnozoology. The Gran Chaco region, the second largest natural biome in South America, is an area of 
great cultural and biological richness and home of several American indigenous hunter-gatherer groups who also practice incipient farming. There are currently seventeen different ethnic groups belonging to six linguistic families (Zamuco, Mataco-Mataguayo, Guaycurú, Tupí-Guaraní, Maskoy and Arawak), involving a total of 200,000 individuals (CENSO 1981; Arenas 1997). Associated with a highly diverse environmental context, Chaco people are renowned for their knowledge of nature; no aspect of their lives, from material aspects to their world view, is unconnected to living beings. Special attention has been given to the relation that different ethnic groups of Chaco have with plants, providing an important scientific contribution to ethnobotany (Arenas 1997). However, studies regarding ethnozoology and the role and significance of animals for the ethnic groups of this region are scarce. Some of the studies we can mention describe animal gathering (Vuoto 1999), food ethnography (Arenas 2003), medicinal and magical uses (Arenas 1987; Arenas and Braunstein 1981; Bourdy et al. 2004), vernacular zoological nomenclature (Martínez Crovetto 1995), and the linguistic dimension of the latter (Cúneo 2009; Cúneo and Porta 2009). Some brief critical reviews by the indigenous communities themselves can also be suggested, such as those written by the Toba Zacarías (1993), or intercultural studies like those of Medrano et al. (2011). Although not from an ethnozoological viewpoint, Altrichter's research (2006) focuses on a sustainable use of fauna, highlighting the dietary and economical importance some vertebrate species have for the mestizo populations of the semiarid Argentine Chaco.

As Arenas $(2000,2009)$ points out in his reviews on the vernacular medicine of the Gran Chaco ethnic groups, the specific ethnomedical studies of the regional fauna awoke the interest of different researchers. More specifically, an extensive list of animal remedies was documented for the Pilagá ethnic group, which belongs to the Guaycurú linguistic filiation (which also includes the Tobas), in an area close to our research site (Filipov 1997). Other references for members of the same linguistic family provide a detailed description of the medicinal applications of birds in a vast ethnoornithological study carried out by Arenas and Porini (2009) on the Tobas of Western Formosa. There are also studies of other Toba groups, such as the Tackshek Tobas from east Formosa, showing the role and significance of animals in their religion and view of the world (Terán 1994, 1998a,b, 2000; Terán 2006; Wilbert and Simoneau 1982; Ruiz Moras 2001). These studies also describe the myths, stories and spiritual representations of the animals and their connection with shamanism, aspects that are closely related to their traditional medicine.

Regarding the Toba (qom) communities of Central Chaco, information available is fragmented and restricted to the medicinal application of some animal species for maternal-infant health (Martínez 2007; Hecht et al. 2008), parasitic diseases and skin affections (Martínez and Barboza 2010), and odontostomatology (Martínez 2010a), as well as details associating animals with food and/or religiousmedical taboos (Martínez 2010b).

Although the use of animals for medicinal purposes is becoming less frequent among the Chaco ethnic groups, many applications require exploitative activities, either gathering, hunting and/or fishing the specimens, the impact of which still remains to be determined. In this sense, the Gran Chaco area is a particularly relevant area due to the number of threatened species it has, as it is under constant pressure by environmental problems such as deforestation (associated to habitat fragmentation), advancing agricultural and farming frontiers, subsistence, commercial and sport hunting and/or fishing, wildlife trade, and others (Altrichter 2006; Bucher and Huszar 1999; Chebez 2008a,b,c, 2009; Karlin et al. 1994; Zak et al. 2004). 
The aim of this study is to determine the animal species that are relevant for a community of Central Chaco Tobas (qom), from an ethnozoological approach, studying specific medicinal uses in order to develop future priorities and strategies of regional conservation. Specific objectives have been designed to:

a) qualitatively document and determine the knowledge, significance and use of invertebrates and vertebrates from the Chaco forest within a Toba (qom) cultural and medical context;

b) quantitatively characterize the medicinal animal species used, taking into account the number, type, frequency, consensus and importance given to them by the community;

c) identify medically relevant species and determine local conservation priorities according to the relevance and type of medicinal use given to the species, also considering other non-medicinal applications described in other studies.

\section{Material and Methods}

\section{Study area}

The study area is part of the Gran Chaco region, a vast sedimentary plain of $1,000,000 \mathrm{~km}^{2}$ that extends north and south of the Tropic of Capricorn and includes the areas of Northern Argentina, Western Paraguay, Southeast Bolivia and part of Southeast Brazil. Involving ten provinces, $58 \%$ of the American Chaco belongs to Argentina and constitutes the vastest forest area in the world as well as one of the most endangered ecoregions of the planet (Karlin et al. 1994; Red Agroforestal Chaco 1999; Zak et al. 2004). Characterized by a great diversity of environments and species, the Chaco is not a homogenous region, varying significantly according to the amount and distribution of rainfall that decreases from East to West. Two macrounits are defined in relation to this gradient: the Humid or Oriental Chaco and the Dry or Occidental Chaco (Adámoli et al. 1990).

This area is located in the province of Chaco (Northeast Argentina) in the surroundings of the Bermejito River, the ancient river bed of the Río Bermejo (Figure 1). 
Martínez 2013. Use of fauna in the traditional medicine of native Toba (qom) from the Argentine Gran Chaco region: an ethnozoological and conservational approach. Ethnobio Conserv 2:2

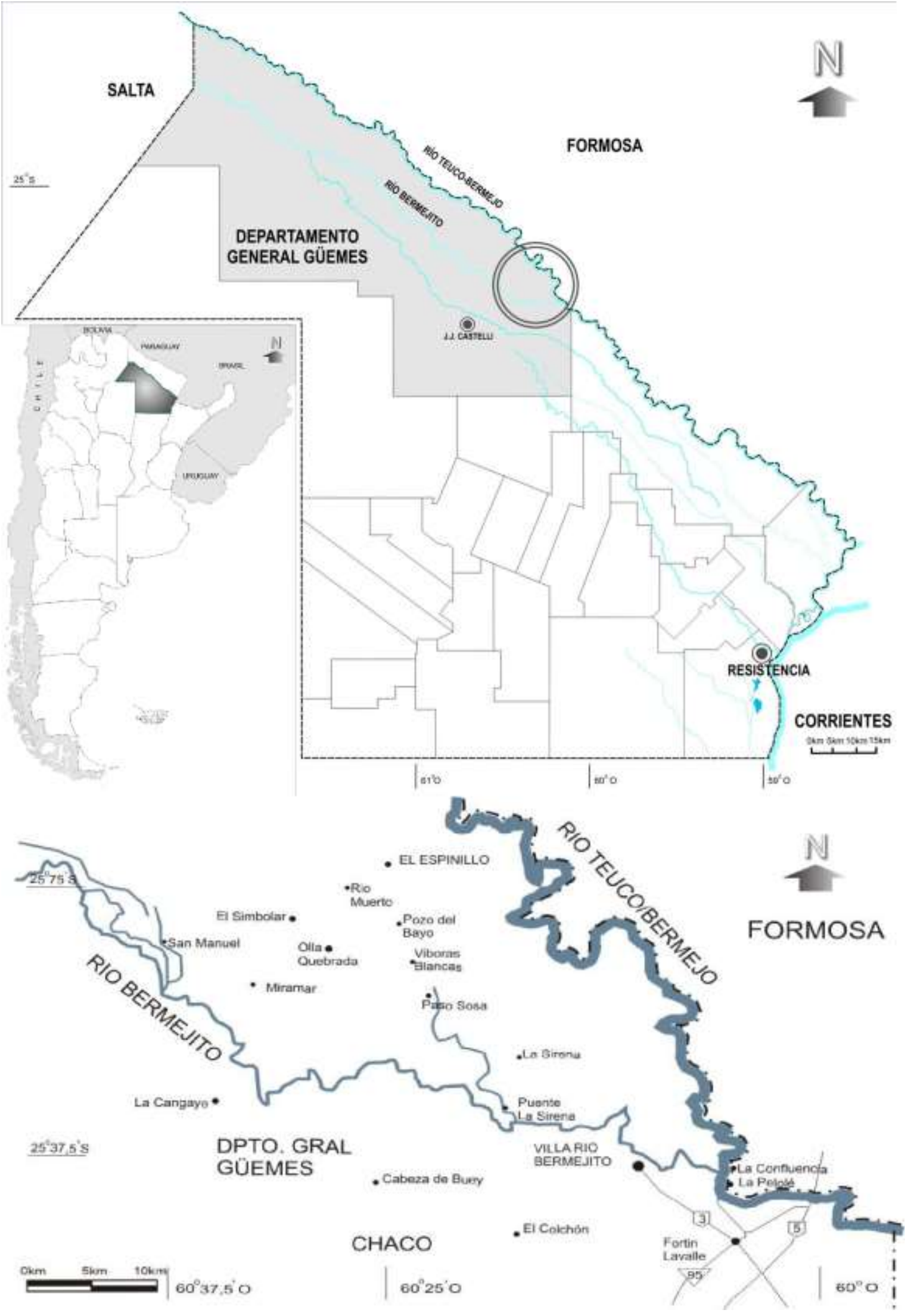

Figure 1. Study area comprising the centre Province of Chaco, in Northeast of Argentina. 
According to its phytogeographical features, corresponds to the Neotropical region of the Chaco Domain, Chaco Province, with species belonging to the Central Chaco forests, following Prado (1993), or to the transition between the Oriental or Humid Chaco and the Occidental or Dry Chaco or Semiarid Chaco, following Cabrera (1994). This is characterized by a subtropical continental climate, with a rainfall of 800-900 $\mathrm{mm} / \mathrm{year}$, an average temperature of $29^{\circ} \mathrm{C}$ in summer and a marked dry season in winter with an average temperature of $17^{\circ} \mathrm{C}$. The landscape is defined by marked fluvial modeling (Morello and Adámoli 1974) and the vegetation consists of a xerophytic deciduous forest together with savannas, halophytic steppes, cardonales, grasslands and shrublands. Due to the presence of continuous forest blocks in a good conservation state, a great diversity of habitats and the presence of emblematic and/or threatened species, conservation organizations have declared this region (the fluvial valley of the Bermejo and the area of the Impenetrable) as a priority area for its vast biodiversity (Asta 2006).

The Chaco wildlife is not only rich in biodiversity but also in species; it plays a highly relevant ecological role in the local environment. It is also an invaluable economical resource for the subsistence of local communities providing meat, skins, feathers, hides and other supplies (Karlin et al. 1994). From a zoographic perspective, and according to Ringuelet (1970), the study area belongs to the Neotropical Region-Guayanobrasilean Subregion, within the Subtropical districtChaco subdistrict. It is estimated to have more than 600 vertebrate species, including over 400 species of birds, almost a hundred reptiles and a slightly lower number of mammals, amphibians and fish. Bucher (1980), Karlin et al. (1994) and Arenas (2003), each presented a detailed list of species abundant/largely found in Chaco ecosystems, focusing on ecological aspects, economically and commercially productive exploitation, food resources and ethnobiological importance.

The diversity of mammals in Chaco is not very abundant and is currently decreasing; it is easy to identify species adapted to the diversity of landscapes and environments. Edentates are especially relevant as a source of food and medicine for the natives, and include the anteater (Myrmecophaga trydactila) as well as armadillos such as the "tatú carreta" (Priodontes giganteus), the "mulita" (Dasypus spp.), the three-banded armadillo locally known as "mataco or quirquincho bola" (Tolypeutes mataco), and the "peludo" (Euphractus spp.). Animal food resources in the wetlands are also highly significant not only for the great number of bird species but also for the presence of mammals that, for different reasons, are fundamental to the subsistence of local communities, providing food, hides and medicine, such as the capybara or "carpincho" (Hydrochaeris hydrochaeris) and the river rat or "nutria" (Myocastor coypus).

The bird wildlife is particularly rich in this region with so many different environments, and includes a long list of species especially aquatic. In the savannas and grasslands we find, among others, small partridges (Nothura maculosa), tinamous (Rhynchotus rufescens, Eudromia formosa) inambues (Crypturellus sp.) and rheas (Rhea americana). There are also species of the Falconidae family and other raptors like the black vulture (Coragyps atratus) and species of Caprimulgidae and Strigidae.

The most popular reptiles of Chaco are the tegu, "iguana" or "lagarto overo" (Tupinambis spp.) and the broad-nosed caiman or "yacaré ñato" (Caiman latirostris chacoensis), this last being a highly threatened species living in small lakes and watercourses. There are also non-poisonous snakes like the Argentine boa constrictor or "lampalagua" (Boa constrictor occidentalis) and poisonous snakes like 
large and small "yararas" (Bothrops alternatus and B. neuwiedii) and "coral" snakes (Micrurus frontalis).

The region also provides many amphibian habitats, large lakes, open grasslands prone to floods, patches of palm forests, riverside jungles and bushy low montes. The most common fish found in reservoirs and rivers are "sabalo" (Prochilodus platensis), "dorado" (Salminus maxillosus), "palometas" (Serrasalmus sp.), catfish or "bagres" (Pimelodus) and rays (Potamotrygon spp.).

The invertebrate fauna remains fairly unknown (Bucher 1980; Arenas 2003). The most relevant species from an ethnobiological point of view are mollusks found in wetlands (Pomacea canaliculata, Anodontites trapesialis, and others). Leaf-cutter ants of the Atta and Acromyrmex genera are also important herbivores of the Chaco ecology. In addition, termites are common in forests and a diversity of bees and wasps provides honey and other subproducts for local inhabitants.

\section{The Tobas (qom) from Central Chaco (Argentina)}

The Tobas, also known as qom or qoml'ek, are an indigenous group belonging to the Guaycurú linguistic family that includes a population of allied bands with about 80.000 members. Their current habitat is mostly confined to the area of Central and Southern Chaco (in the provinces of Chaco and Formosa, Argentina), as well as other urban sites in the provinces of Santa Fe and Buenos Aires, and a small nucleus in the Northern Chaco area in Paraguay (ENDEPA 1986; Censabella 2000). As other typical Chaco ethnic groups, they were historically divided into bands of large bloodrelated families, which in generally were hunter-gatherers (Braunstein 1983; Miller 1979). Today, this tradition has gradually evolved into a more sedentary lifestyle occupying territories. Most Tobas in this region develop some form of family subsistence economy in which products from the forest have an important role. From an economical point of view, the Tobas subsist on a combination of hunting, fishing and gathering, together with an incipient agriculture, management of goat herds, apiculture and paid handwork for cotton harvesting, selling forest resources, participation in non-governmental organizations, and aid from government help plans (Martínez 2008).

The local health system is characterized by a multiple sanitary context that includes shamanism (carried out by specialists known as pioxonac), domestic or homemade medicines and the official medicine (biomedicine) provided in health care centers run by doctors and Toba sanitary agents. Despite this pluralism, traditional Toba medicine is still not incorporated to the official medicine even though the use of natural remedies and shamanic cures are one of the main therapeutic options to which local inhabitants appeal (Martínez 2007, 2011).

\section{Field work and data collection}

During the 2004-2009 period, six etnobiological field assays were carried out. This implied staying for more than 100 days at different Toba settlements located in the surroundings of the Bermejito River, in the Río Bermejito district (Department of General Güemes, province of Chaco). Most interviews were carried out at the community of El Colchón although additional information was obtained from other sites. Before being interviewed, community members were briefed on the research project and its academic objectives. Conversations with specialists and inhabitants were based on a common objective: to improve conservation goals, increase 
knowledge regarding natural remedies and develop educational materials of local interest, as suggested in the guidelines of the International Society of Ethnobiology Code of Ethics (2008).

Qualitative, quantitative and participative methods were used alternatively in different recurring instances throughout the investigation, trying to improve each new instance with previous results and following the basic scheme of an ethnobiological study: field work and laboratory work. We consider it important to highlight the epistemological difference between the cognitive systems of the human study group and that of the observer, known as the "emic" and "etic" accounts respectively, to adequately translate the local categories into occidental terms (Anderson et al. 2011; Martin 2000).

A total of 60 informers including specialists (shamans, midwives and elderly people) and community members (youngsters and adults of both sexes) were subjected to a previously designed semi-structured thematic questionnaire; open, extensive and recurring interviews were also conducted. The same were designed based on Arenas (1995) regarding topics on vernacular medicine. This information was complemented with data obtained by participative observations and in participative workshops involving members of the community.

The invertebrate zoological material was identified by specialists and is part of the author's personal collection (Museo de Antropología). Vertebrates were identified with the aid of local qualified informers using photographs and images in field guides as visual stimulus. In addition, data reported by colleagues on fieldwork with Toba communities, who systematized nomenclature of fish, birds and mammals on the basis of observations and collaborative sessions between researchers and natives (sharing hunting and fishing activities and visiting local zoos, aquariums, recordings of bird songs, among others), were considered (Cúneo 2009; Cúneo and Porta 2009; Medrano et al. 2011). This allowed us having a Toba (qom) zoonimia appropriate that was used as a reference to establish correspondence between one or more ethnospecies (on the basis of their vernacular name) and their taxonomic species. Likewise, this material was corroborated via specific ethnobiological references for the Gran Chaco region, all based on thoroughly documented information (Martínez Crovetto 1995; Arenas 2003; Arenas and Porini 2009).

\section{Data analysis}

To fulfill each of the specific objectives of the study, the ethnozoologic information was analyzed considering the following methodological techniques:

Qualitative methods: the results of open extensive interviews and participative observation data were studied to interpret and identify the role of animal pharmacopoeia in Toba ethnomedicine, trying to respect and describe the local representations, significances and viewpoints (Valles 2000), particularly regarding issues related to the native cosmology.

Quantitative methods: Quantitative assessments were based on the number of uses reported for each species (categorized according to the frequency of mention) and the proportion they represented in the total number of reports. The data was then systematized in an Excel (Office 2000) database and a quantitative analysis was carried out using the Dynamic Tables function. 
Additionally, an index catalogue was comprised including qualitative and quantitative information regarding the species and medicinal uses, and indicating the degree of consensus between the informers. The information was categorized according to the following aspects:

a) Level of taxonomic categories: we systematically analyzed the animal species involved with descriptive statistics. The number of species and documented uses were used as the basic unit of analysis.

b) Ethnopharmacological uses: we considered the number of use reports for each species and the consensus between informers regarding each specific use (Benz et al. 1994). We then determined the following indexes:

- Informant Consensus Factor (FIC): a measure of consensus between informers for each health area. This index determined whether the studied human group has specific criteria for choosing the species used. Thus, the FIC (Heinrich et al. 1998; Schlage et al. 2000) was calculated as:

$\mathrm{FIC}=$ nur $-\mathrm{nt} /$ nur -1

where

nur = number of use-reports in each category;

$\mathrm{nt}=$ number of species used;

FIC ranges from 0 to 1 . A high value (close to 1) indicates high consensus, whereby relatively few species are used by many people; a low value indicates that the informants disagree on the taxa used for treating a particular illness.

Percentage of Uses Reported (\% Ur): the ratio between the number of medicinal use reports for each species and the total number of medicinal reports.

Relative Importance of Species (RI): it values the medicinal species according to the number of pharmacological properties (NP) attributed to the taxon (eg. analgesic, diuretic) and the number of body systems (BS) to which it is applied (eg. urology, gastroenterology), as proposed by Bennet and Prance (2000):

$\mathrm{RI}=(($ Rel NP + Rel BS $) \% 2) \times 100$

where:

Rel NP: relative number of pharmacological properties attributed to a species (normalized to a maximum value of 1 );

Rel BS: relative number of body systems or health areas treated with a determined species (normalized to a maximum value of 1 ).

c) Identification of relevant medicinal species and local conservation priorities. In addition to the value of RI, the following secondary sources of complementary information were also considered to assess the impact of extraction on species used for medicinal purposes compared to other applications, taking into account the local ecological characteristics.

- $\quad$ Ecological and cultural value of species (ECV): use as a food source (how it is obtained, hunting, fishing and/or gathering method); other uses in the different Toba 
communities of the Gran Chaco that evidence some sort of sociocultural value for the species such as magical or religious uses, predictive uses, proximity or relation to shamanism, uses as a cultural material, and other uses described by Vuoto (1999), Martínez Crovetto (1995), Arenas (2003), Arenas and Porini (2009); presence and/or absence in relevant mythical stories of the Toba cosmology (Wilbert and Simoneau 1982; Terán 1994); ecological information such as taxonomic uniqueness or key ecological role of the species.

- $\quad$ Species Conservation Status (CS): based on references and databases for Argentina, we assigned a value to each species considering the reports of Chebez (2008a,b,c, 2009) and the Database of the Sistema de Información de Biodiversidad (Biodiversity Information System) of the Administration of National Parks (http://www.sib.gov.ar), which includes information from the Argentine Society of Mammal Studies (SAREM), the Argentine Herpetological Association (AHA) and comprehensive local bibliography. In the absence of local information, the conservation status follows the IUCN categories proposed in the Red List of Threatened Species (IUCN 2011: http://www.iucnredlist.org), and information on international trade regulation extracted from the Convention on International Trade in Endangered Species, (CITES 2011: hhtp://www.cites.org/eng/resources/species.html). When there were differences in criteria regarding the category assigned by different sources, we chose the one with the highest level of protection.

Based on algorithms similar to those used in other reports regarding conservation priorities for medicinal plants (Dhar et al. 2000; Martínez et al. 2006), we determined an Index of Local Conservation Priorities (ILCP) according to the following formula:

$$
\mathrm{ILCP}=(\text { Cat RI * Cat ECV * Cat CS }) \text { * } 100 / \sum(\text { Cat RI * Cat ECV * Cat CS })
$$

This index combines the numerical values of each of the three categories, RI, ECV and CS, assigned with a value of 1 to 5 according to the indicators and/or criteria shown in Table 1, based on the aforementioned information. This index provides a numerical value that allows arranging species comparatively according to the local conservation priorities. 
Martínez 2013. Use of fauna in the traditional medicine of native Toba (qom) from the Argentine Gran Chaco region: an ethnozoological and conservational approach. Ethnobio Conserv 2:2

Table 1. Indicators and criteria for assigning numerical values to the categories RI, ECV and CS. (NS: National Status; IS: International Status)

\begin{tabular}{|c|c|c|c|}
\hline $\begin{array}{c}\text { Value } \\
\text { assigned }\end{array}$ & $\begin{array}{c}\text { Categories of } \\
\text { Medicinal Relative } \\
\text { Importance (RI) } \\
\text { (S.D.= Standard } \\
\text { deviation) } \\
\end{array}$ & $\begin{array}{c}\text { Categories of Ecological and } \\
\text { Cultural Value (ECV) }\end{array}$ & $\begin{array}{c}\text { Categories of } \\
\text { Conservation Status } \\
\text { (CS) }\end{array}$ \\
\hline 5 & > Mean RI + 3 S.D. & $\begin{array}{l}\text { - Key ecological role and taxonomic } \\
\text { singularity } \\
\text { - Hunting, fishing and indiscriminate } \\
\text { and illegal collection for various } \\
\text { purposes; marketing and traffic in } \\
\text { the present or in the past } \\
\text { - Sociocultural and / or mythical- } \\
\text { religious valorization of the specie }\end{array}$ & $\begin{array}{l}\text { NS: Endangered } \\
\text { IS (UICN): CR } \\
\text { (Critically } \\
\text { Endangered) / EN } \\
\text { (Endangered) } \\
\text { Cites I }\end{array}$ \\
\hline 4 & $\begin{array}{l}<\text { Mean } \mathrm{RI}+3 \text { S.D. } \\
>\text { Mean } \mathrm{RI}+2 \text { S.D. }\end{array}$ & $\begin{array}{l}\text { - Hunting, fishing and frequent } \\
\text { collection for various purposes, not } \\
\text { marketable } \\
\text { - Sociocultural and / or mythical- } \\
\text { religious valorization of the specie }\end{array}$ & $\begin{array}{l}\text { NS: Threatened } \\
\text { IS (UICN): V } \\
\text { (Vulnerable) } \\
\text { Cites II }\end{array}$ \\
\hline 3 & $\begin{array}{l}<\text { Mean RI + } 2 \text { S.D. } \\
>\text { Mean RI + } 1 \text { S.D. }\end{array}$ & $\begin{array}{l}\text { - Hunting, fishing and occasional } \\
\text { collection for various purposes, not } \\
\text { marketable } \\
\text { - Sociocultural and / or mythical- } \\
\text { religious valorization of the specie }\end{array}$ & $\begin{array}{l}\text { NS: Vulnerable } \\
\text { IS (UICN): NT (Near } \\
\text { Threatened) } \\
\text { Cites III }\end{array}$ \\
\hline 2 & $\begin{array}{l}<\text { Mean RI + 1 S.D. } \\
>\text { Mean RI }\end{array}$ & $\begin{array}{l}\text {-Hunting, fishing and inconspicuous } \\
\text { or infrequent collection for various } \\
\text { purposes, not marketable } \\
\text { - With or without Sociocultural and / } \\
\text { or mythical-religious valorization of } \\
\text { the specie }\end{array}$ & $\begin{array}{l}\text { NS: Not threatened, } \\
\text { Minor risk, } \\
\text { IS (UICN): LC (Least } \\
\text { Concern) }\end{array}$ \\
\hline 1 & $<$ Mean RI & $\begin{array}{l}\text { - Absence or insignificant hunting, } \\
\text { fishing or collecting, or non- } \\
\text { extractive uses (symbolic) } \\
\text { - Without sociocultural and / or } \\
\text { mythical-religious valorization of the } \\
\text { specie }\end{array}$ & $\begin{array}{l}\text { NS: Indeterminate } \\
\text { Deficient data or } \\
\text { without information } \\
\text { Widespread species } \\
\text { Introduced species }\end{array}$ \\
\hline
\end{tabular}

\section{Results and Discussion}

\section{General characterization of the animal pharmacopoeia}

As reported by 60 informants, a total of 199 uses corresponding to 72 species from 52 families were documented as part of the animal pharmacopoeia used in the Toba (qom) traditional medicine of Central Chaco. Table 2 describes the species, applications, and quotation frequency. As can be seen, over $80 \%$ of animal species allows for 2 or 3 different medicinal uses; only 10\% reaches six validated uses. On average were cited 4.74 animals per person. In addition, and considering the total amount of reports of medicinal use $(n=942)$, a high rate of medicinal uses 
documented spontaneously (in $65 \%$ of the species) are reports from up to 10 informants. This would reveal that a major part of medicinal knowledge is carried by a relatively low amount of people, which would indicate it is a specialized knowledge shared among or passed on to the various Toba households, but not with the entire ethnic group under study.

Most of the local taxa is composed of native species (87\%, $62 \mathrm{spp}$.$) , except for$ introduced domestic species (Equus spp., Ovis aries, Capra hircus, Sus scrofa) and the introduced bee (Apis mellifera) that only make up for $13 \%$ of the total number of species used.

The analysis of species composition (Figure 2) shows that vertebrates are more relevant than invertebrates. The former includes a relevant number of Mammals, Birds and Reptiles, while the latter shows a clear predominance of Insects. Likewise, Table 3 shows a greater number of medicinal uses for vertebrates with a number of uses/number of species ratio of 3.08 compared to 1.89 for invertebrates. The same table shows high values of the number of uses/number of species ratio for Classes like Bivalves and Reptiles, which is explained by their low number of species and medicinal families and wide range of uses as in the case of Anodontites trapesialis and Tupinambis merianae, belonging to each Classes respectively. If we compared these groups with the largest number of medicinal species in the region studied, in view of those reported by Alves and Alves (2011) for Latin America, we note that 9 out of the 13 taxonomic categories mentioned are represented in Toba zootherapy; these also follow almost the same order regarding number of medicinal species (mammals followed by birds, reptiles and insects), except fish, lower in number for being from a predominantly hinterland group.

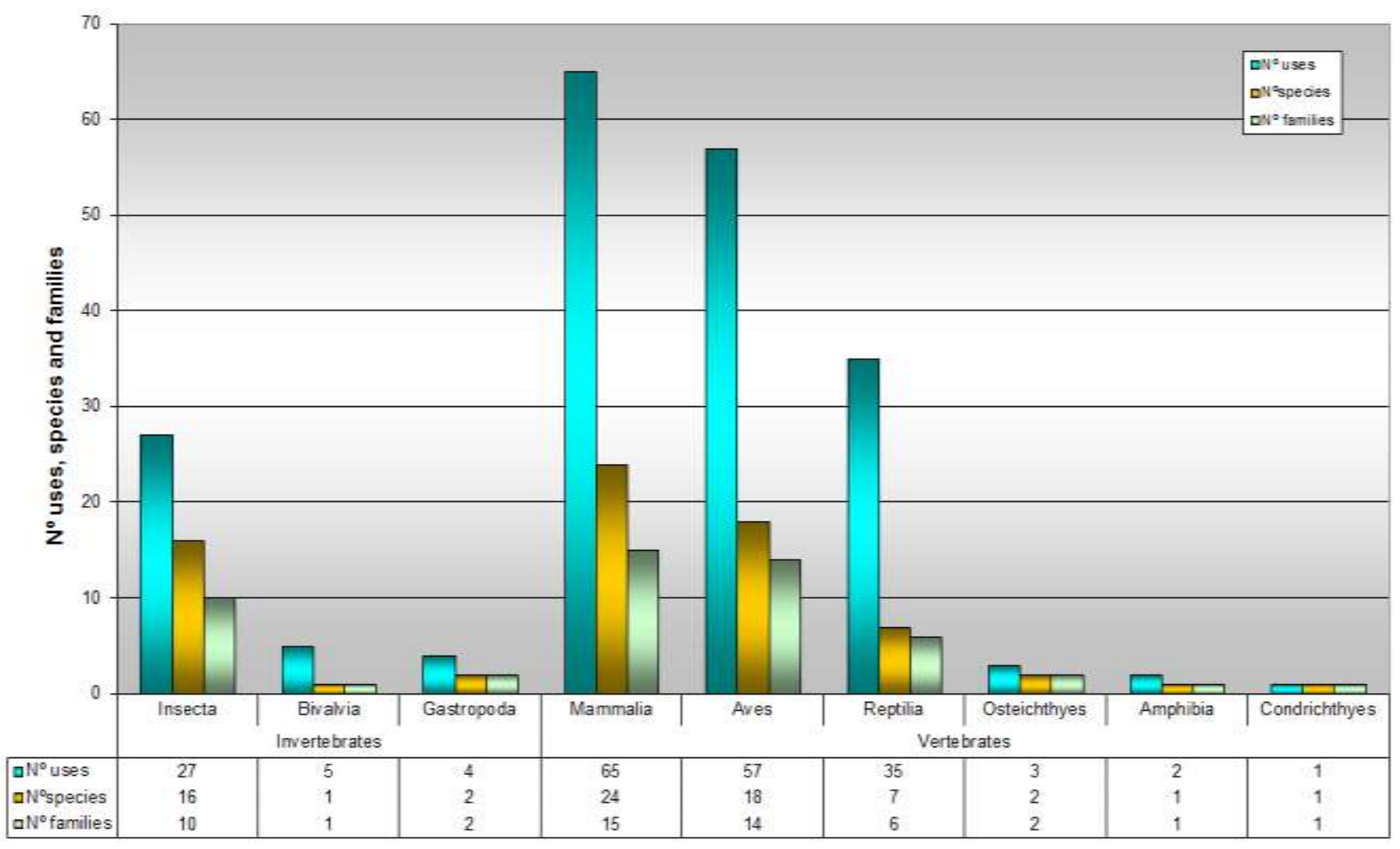

Figure 2. Number of uses, species and families by taxonomic category (Class and Group). 
Martínez 2013. Use of fauna in the traditional medicine of native Toba (qom) from the Argentine Gran Chaco region: an ethnozoological and conservational approach. Ethnobio Conserv 2:2

Table 2. Animal remedies used in the traditional medicine of the Toba (qom) community from Central Chaco (Argentina) (Origin; N: Native; I: Introduced; Quotation frequency: * $<5 \%$ of the informants; ${ }^{* *} 5-10 \%$ of the informants; ${ }^{* *} 10-15 \%$ of the informants, ${ }^{* * * *} 15-25 \%$ of the informants, ${ }^{* * * *} 25-35 \%,{ }^{* * * * * *}>35 \%$ of the informants)

\begin{tabular}{lllll}
\hline CLASS & Species & Local name & Orig & $\begin{array}{l}\text { Part use, Way of preparation and } \\
\text { Family }\end{array}$ \\
\hline
\end{tabular}

PHYLUM ARTHROPODA

INSECTA

Apidae Apis mellifera L.

Scaptotrigona sp

rapic, dapic (peluquera, yana)

piroxonac (mestizo)

coilala (rubiecita)

Trigona sp. esaxalta, te'esaq Ita'a (abeja, extranjera)

Honey / Food intake

Larvae/food intake

"Hámago" dissolved in water / Food intake

Honey / Eye drops and bath

"Hámago" dissolved in water / Food intake

Honey / Food intake

Honey / Eye drops and bath

Larvae / Food intake

nvī̃o

(chicharra)

$\begin{array}{ll}\text { Indet. } & \text { nviỹo' } \\ \text { (chicharra) }\end{array}$

Cough

(expectorant): A spoon of honey, oil and lemon is prepared and eaten warm

Sore throat (Antibiotic, oropharyngeal antiseptic)

Fluctuations in blood pressure

Loss of appetite, anorexia, (tonic)

Constipation. 'Hámago' or yellow pollen of the inner of a trunk is extracted and dissolved in water, as a juice which is drunk as a laxative

Eye conditions

(Anti-ophtalmic)

Constipation

Hypertension

Sore throat (Antibiotic, oropharyngeal antiseptic)

Eye conditions

(Anti-ophtalmic)

Larvae of this insect are consumed to quench deep thirst (polydipsia)

Anuria: Infusion is prepared with the "pelecho" of the ratchet (nviỹo 'Ivi'), since this insect has water every day. Also rub the bladder region of the child to urinate.

Land of the nest is used to cicatrize the navel of the newborn

Its abdomen is used to rub the groin and bladder, along with ash to treat bedwetting and to develop sphincter control, as it 
Martínez 2013. Use of fauna in the traditional medicine of native Toba (qom) from the Argentine Gran Chaco region: an ethnozoological and conservational approach. Ethnobio Conserv 2:2

\begin{tabular}{|c|c|c|c|c|c|c|}
\hline $\begin{array}{l}\text { CLASS } \\
\text { Family }\end{array}$ & Species & $\begin{array}{l}\text { Local name } \\
\text { ('Criollos' name) }\end{array}$ & $\begin{array}{l}\text { Orig } \\
\text { in }\end{array}$ & $\begin{array}{l}\text { Part use, Way of preparation and } \\
\text { administration, (Recipe) }\end{array}$ & Application (Therapeutic effect attributed) & $\begin{array}{l}\text { Frequency } \\
\text { (\%) }\end{array}$ \\
\hline & & & & & is considered that the excretas of this ant are never seen. & \\
\hline & & & & Animal// Infusion or decoction/ Beverage & Drink a decoction of three ants in a kettle as a diuretic & * \\
\hline Grillotalpidae & $\begin{array}{l}\text { Scapteriscus borelli Giglio } \\
\text { Tos }\end{array}$ & millic (grillo) & $\mathrm{N}$ & Animal/ Roast/ Food intake & $\begin{array}{l}\text { Acquisition of speech: a child who speaks little or is stutterer } \\
\text { is cured by feeding a roasted cricket }\end{array}$ & $* \star \star \star * *$ \\
\hline Gryllidae & Gryllus argentinus Saussure & millic (grillo) & N & Animal/ Roast/ Food intake & $\begin{array}{l}\text { Acquisition of speech: see recipe in S. Borelli. It is used after } \\
\text { weaning to prevent breast bites. Drawbacks: child can bite its } \\
\text { peers or speak a lot when he must shut up. }\end{array}$ & $* \star \star \star \star *$ \\
\hline \multirow[t]{2}{*}{ Mantidae } & $\begin{array}{l}\text { Coptoteryx argentina Giglio- } \\
\text { Tos, } \\
\text { Stagmatoptera hyaloptera }\end{array}$ & $\begin{array}{l}\text { quedenaxai'chi } \\
\text { (mamboretá) }\end{array}$ & $\mathrm{N}$ & Ootheca/ Body gadget & $\begin{array}{l}\text { Tooth decay and toothache: hang the ootheca with eggs from } \\
\text { a thread to relieve pain, as this insect is considered to eat the } \\
\text { "worms" that cause toothache }\end{array}$ & * \\
\hline & Perty & & & & & \\
\hline \multirow[t]{2}{*}{ Psychidae } & $\begin{array}{l}\text { Oiketicus kirbyi Lands } \\
\text { Guilding }\end{array}$ & cotaxat (bicho canasta) & $\mathrm{N}$ & Cocoon/ Body gadget & It is used as a pendant shaped body medal or ring. & * \\
\hline & & & & Coccon/ Incineration / Topical & Ashes are applied in mouth sores and fires & * \\
\hline \multirow[t]{3}{*}{ Termitidae } & Nasutitermes sp. & chep pilaxai (termitero) & $\mathrm{N}$ & Nest/ Macerated in water/washings & $\begin{array}{l}\text { Muscolskeletal disorders: it is especially indicated for people } \\
\text { with disabilities; once the bath finishes, the liquid should be } \\
\text { discarded in west direction, thus shedding the evil }\end{array}$ & * \\
\hline & & & & Nest/ Infusion or decoction/ Bevarage & Against cough & ${ }_{* \star *}^{* *}$ \\
\hline & & & & & $\begin{array}{l}\text { Against wheezing and asthma } \\
\text { Boil pieces of the nest and drink hot alone, or with honey and } \\
\text { sugar. Nests that grow in 'mistoles', 'algarrobos' and } \\
\text { 'quebrachos' are preferred. It is especially indicated for } \\
\text { smoker's cough. }\end{array}$ & **** \\
\hline Vespidae & $\begin{array}{l}\text { Polistes spp. }{ }^{*} \text { (Polistes cfr. } \\
\text { canadensis and other spp.) }\end{array}$ & $\begin{array}{l}\text { uootel (carán negro, } \\
\text { carán colorado) }\end{array}$ & $\mathrm{N}$ & Honeycomb/ Incineration / Topical & Ashes are applied in mouth sores and fires & **** \\
\hline \multirow[t]{2}{*}{$\begin{array}{l}\text { Not determined (Orden } \\
\text { Lepidoptera) }\end{array}$} & $\begin{array}{l}\text { Not determined: chrysalis } \\
\text { state }\end{array}$ & cochel (gusano) & & Cocoon/ Incineration/ Topical & $\begin{array}{l}\text { Apply the ashes on the opened head of children affected by } \\
\text { "evil-eye" }\end{array}$ & * \\
\hline & & & & Cocoon/Incineration/ Simbolic action & Tooth decay and toothache & * \\
\hline
\end{tabular}

\section{PHYLUM MOLLUSCA}

\section{BIVALVIA}


Martínez 2013. Use of fauna in the traditional medicine of native Toba (qom) from the Argentine Gran Chaco region: an ethnozoological and conservational approach. Ethnobio Conserv 2:2

\begin{tabular}{|c|c|c|c|c|c|c|}
\hline $\begin{array}{l}\text { CLASS } \\
\text { Family }\end{array}$ & Species & $\begin{array}{l}\text { Local name } \\
\text { ('Criollos' name) }\end{array}$ & $\begin{array}{l}\text { Orig } \\
\text { in }\end{array}$ & $\begin{array}{l}\text { Part use, Way of preparation and } \\
\text { administration, (Recipe) }\end{array}$ & Application (Therapeutic effect attributed) & $\begin{array}{c}\text { Frequency } \\
(\%)\end{array}$ \\
\hline & & agua) & & & & \\
\hline & & & & & Burns & * \\
\hline & & & & & $\begin{array}{l}\text { Bites. It is especially indicated for bites of the fish line } \\
\text { (Potamotrygon sp.) }\end{array}$ & ** \\
\hline & & & & & $\begin{array}{l}\text { Newborn care and treatment. Ashes are used to cicatrize the } \\
\text { navel of the newborn }\end{array}$ & $* * * *$ \\
\hline & & & & & $\begin{array}{l}\text { Ashes are applied locally to heal and relieve discomfort in the } \\
\text { child's mouth during breast-feeding. They are also used to } \\
\text { treat mouth sores and fires. }\end{array}$ & $* * \star \star *$ \\
\hline \multicolumn{7}{|l|}{ GASTROPODA } \\
\hline \multirow[t]{4}{*}{ Ampullariidae } & Pomacea canaliculata Lam. & $\begin{array}{l}\text { Sapo Ico'oue' (Huevo de } \\
\text { "sapo") }\end{array}$ & & Eggs / topical use & Burns & * \\
\hline & & & & Eggs /friction and massages & "Laiel" or kickstand "pata de cabra" & * \\
\hline & & & & Eggs / topical use & Mouth sores and fires & $* * *$ \\
\hline & $\begin{array}{l}\text { Strophocheilus oblongus } \\
\text { Müller }\end{array}$ & nashiỹo (caracol) & $\mathrm{N}$ & Shell / Symbolic action & $\begin{array}{l}\text { Acquisition of speech: used as a glass to drink water. More } \\
\text { details in Martinez (2007) and Hecht et al. (2008) }\end{array}$ & $* * * * * *$ \\
\hline \multicolumn{7}{|c|}{ PHYLUM CHORDATA } \\
\hline \multicolumn{7}{|c|}{ CONDRICHTHYES } \\
\hline Dasyatidae & Potamotrygon sp. & lacataic (raya) & $\mathrm{N}$ & Venomous stings/ Incision & $\begin{array}{l}\text { Toothache and tooth decay The plectrum from the stingray tail } \\
\text { is used to pierce the aching teeth and eliminate pain. }\end{array}$ & * \\
\hline \multicolumn{7}{|c|}{ OSTEICHTHYES } \\
\hline Curimatidae & $\begin{array}{l}\text { Prochilodus platensis } \\
\text { Valenciennes }\end{array}$ & nỹaq & $\mathrm{N}$ & $\begin{array}{l}\text { Fat/Unprepared/External use. Fat from abdomen } \\
\text { is preferred, especially in cases of scratches and } \\
\text { claws }\end{array}$ & Wounds and injuries & ** \\
\hline & & & & Meat/ Roasted / Food intake & Fatigue and weakness (tonic) & * \\
\hline
\end{tabular}


Martínez 2013. Use of fauna in the traditional medicine of native Toba (qom) from the Argentine Gran Chaco region: an ethnozoological and conservational approach. Ethnobio Conserv 2:2

\begin{tabular}{|c|c|c|c|c|c|c|}
\hline $\begin{array}{l}\text { CLASS } \\
\text { Family }\end{array}$ & Species & $\begin{array}{l}\text { Local name } \\
\text { ('Criollos' name) }\end{array}$ & $\begin{array}{l}\text { Orig } \\
\text { in }\end{array}$ & $\begin{array}{l}\text { Part use, Way of preparation and } \\
\text { administration, (Recipe) }\end{array}$ & Application (Therapeutic effect attributed) & $\begin{array}{l}\text { Frequency } \\
(\%)\end{array}$ \\
\hline Serrasalmidae & Serrasalmus sp. & cote (palometa) & $\mathrm{N}$ & Teeth as a hand tool & $\begin{array}{l}\text { Newborn care and treatment: sharp teeth are used to cut the } \\
\text { umbilical cord of the newborn }\end{array}$ & $* *$ \\
\hline
\end{tabular}

AMPHIBIA

Bufonidae Rhinella spp. (R. arenarum) qoloxoloxo (sapo)
N

animal is rubbed on the skin to relieve discomfort.

It must also be exp hessy rovest the ansomfort

carries the disease

Tie a live toad in the bite until it dies in a way that

allows the doctor to arrive on time

REPTILIA

Alligatoridae

Caiman latirostris

da'ail'oc (yacaré)

chacoensis Daudin

Fat/Unprepared/ friction and massages

Meat and fat /Unprepared / Food intake

Snake bites

Muscle pain (anti-inflammatory)

As a cicatrizant for fish "palometa" bites (Serrasalmus sp.)

Flu (Preventive): rub on the child's arms and body

Flu / (Preventive): a necklace of alligator teeth is used to protect and strengthen the child

Protection of the teeth (prevention): chew an alligator tooth to develop healthy and strong teeth

\section{Itching, irritation, rash}

Flu (Preventive): the meat and fat of the alligator are considered very healthy, strengthening and protecting the child 
Martínez 2013. Use of fauna in the traditional medicine of native Toba (qom) from the Argentine Gran Chaco region: an ethnozoological and conservational approach. Ethnobio Conserv 2:2

\begin{tabular}{|c|c|c|c|c|c|c|}
\hline $\begin{array}{l}\text { CLASS } \\
\text { Family }\end{array}$ & Species & $\begin{array}{l}\text { Local name } \\
\text { ('Criollos' name) }\end{array}$ & $\begin{array}{l}\text { Orig } \\
\text { in }\end{array}$ & $\begin{array}{l}\text { Part use, Way of preparation and } \\
\text { administration, (Recipe) }\end{array}$ & Application (Therapeutic effect attributed) & $\begin{array}{l}\text { Frequency } \\
(\%)\end{array}$ \\
\hline \multirow[t]{4}{*}{ Boidae } & $\begin{array}{l}\text { Boa constrictor occidentalis } \\
\text { Phil. }\end{array}$ & $\begin{array}{l}\text { mmi'ic, naxaraxanaaq } \\
\text { late'e (ampalagua, } \\
\text { lampalagua) }\end{array}$ & $\mathrm{N}$ & Fat/ Unprepared / Friction and massages & Eruptive diseases (chickenpox, measles, others). & * \\
\hline & & & & & Earache & * \\
\hline & & & & & Boils and abscesses (Maturative) & * \\
\hline & & & & & Joint conditions (anti-arthritic and anti-inflammatory articular) & $* * * *$ \\
\hline Colubridae & $\begin{array}{l}\text { Hydrodynastes gigas } \\
\text { (Duméril, Bibron \& Duméril) }\end{array}$ & chiglogolli (ñacanina) & $\mathrm{N}$ & Brain/Unprepared/Poultices & $\begin{array}{l}\text { In case of a 'ñacanina' bite, this snake must be killed and its } \\
\text { brain removed to be placed in the affected area, and covering } \\
\text { with a poultice of the leaf of Plantago major }\end{array}$ & * \\
\hline \multirow[t]{9}{*}{ Teiidae } & $\begin{array}{l}\text { Tupinambis rufescens } \\
\text { Günther }\end{array}$ & $\begin{array}{l}\text { toxoxaraic qolliguesaq } \\
\text { (iguana colorada) }\end{array}$ & N & Fat/Unprepared/ Frictions and massages. & $\begin{array}{l}\text { Chagas disease } \\
\text { (Antiinflammatory). It is applied around the inflamed eye } \\
\text { caused by the bite of the insect vector }\end{array}$ & ** \\
\hline & & & & Fat/ Unprepared/Topical use & Eye conditions & ** \\
\hline & $\begin{array}{l}\text { Tupinambis merianae } \\
\text { Duméril \& Bibron }\end{array}$ & $\begin{array}{l}\text { lairaxaic / naigoxonaxa } \\
\text { qolliguesaq (iguana, } \\
\text { lagarto overo) }\end{array}$ & $\mathrm{N}$ & Fat/Unprepared/ Frictions and massages. & $\begin{array}{l}\text { Chagas disease } \\
\text { (Antiinflamnatory) It is applied around the inflamed eye } \\
\text { caused by the bite of the insect vector }\end{array}$ & ** \\
\hline & & & & & Boils and abscesses & ** \\
\hline & & & & & Pimples & ** \\
\hline & & & & & Wounds and injuries & * \\
\hline & & & & & Skin blisters & ** \\
\hline & & & & & Warts & ** \\
\hline & & & & & $\begin{array}{l}\text { Snakebites: chew fat iguana or pass on the bite. The brain of } \\
\text { the iguana is also used over the injuries, since this animal } \\
\text { tolerates them without dying }\end{array}$ & $* * *$ \\
\hline
\end{tabular}


Martínez 2013. Use of fauna in the traditional medicine of native Toba (qom) from the Argentine Gran Chaco region: an ethnozoological and conservational approach. Ethnobio Conserv 2:2

\begin{tabular}{|c|c|c|c|c|c|c|}
\hline $\begin{array}{l}\text { CLASS } \\
\text { Family }\end{array}$ & Species & $\begin{array}{l}\text { Local name } \\
\text { ('Criollos' name) }\end{array}$ & $\begin{array}{l}\text { Orig } \\
\text { in }\end{array}$ & $\begin{array}{l}\text { Part use, Way of preparation and } \\
\text { administration, (Recipe) }\end{array}$ & Application (Therapeutic effect attributed) & $\begin{array}{l}\text { Frequency } \\
(\%)\end{array}$ \\
\hline & & & & & Sore throat (anti-inflammatory) & ** \\
\hline & & & & & Earache & $* * * * *$ \\
\hline & & & & & Whooping cough and cold (expectorant) & * \\
\hline & & & & & $\begin{array}{l}\text { Joint conditions and muscle aches (anti-arthritic and anti- } \\
\text { inflammatory) }\end{array}$ & $* * *$ \\
\hline & & & & & Sprains and twists (anti-inflammatory joint) & ** \\
\hline & & & & Fat/ Unprepared /Topical use & $\begin{array}{l}\text { Toothache and tooth decay: the cavities of the teeth are filled } \\
\text { with fat. }\end{array}$ & * \\
\hline & & & & & Eyes conditions (ophthalmic) & * \\
\hline & & & & Bone / Unprepared / Symbolic actions & $\begin{array}{l}\text { Headaches: heat to fire the bone of the neck of the Iguana to } \\
\text { relieve headache }\end{array}$ & ** \\
\hline \multirow[t]{3}{*}{ Testudinidae } & $\begin{array}{l}\text { Chelonoidis spp. (C. } \\
\text { chilensis / C. carbonaria } \\
\text { Spix) }\end{array}$ & potaxanaxac (tortuga) & $\mathrm{N}$ & Shell /Infusion or decoction / Beverage & diarrhea (antidiarrheal) & * \\
\hline & & & & & (Emetic) & ** \\
\hline & & & & & Cough ( expectorant) & ** \\
\hline Viperidae & $\begin{array}{l}\text { Crotalus durissus terrificus } \\
\text { Laurenti }\end{array}$ & $\begin{array}{l}\text { nlonaq } \\
\text { cascabel) }\end{array}$ & $\mathrm{N}$ & Rattles /Symbolic action & $\begin{array}{l}\text { In case of delays in childbirth, rub the rattles on the abdomen } \\
\text { of the pregnant women }\end{array}$ & ** \\
\hline \multicolumn{7}{|l|}{ AVES } \\
\hline Cariamidae & Chunga burmeisteri Hartlaub & lashenec, lashinec & $\mathrm{N}$ & Manure/Unprepared/Poultice & Boils and abscesses & $* * \star *$ \\
\hline Cathartidae & Coragyps atratus Bechstein & teguesan (cuervo) & $\mathrm{N}$ & Eggs/ Symbolic actions & $\begin{array}{l}\text { Inguinal hernia: heat a crow's egg and place it at the site of } \\
\text { the hernia. }\end{array}$ & * \\
\hline
\end{tabular}


Martínez 2013. Use of fauna in the traditional medicine of native Toba (qom) from the Argentine Gran Chaco region: an ethnozoological and conservational approach. Ethnobio Conserv 2:2

\begin{tabular}{|c|c|c|c|c|c|c|}
\hline $\begin{array}{l}\text { CLASS } \\
\text { Family }\end{array}$ & Species & $\begin{array}{l}\text { Local name } \\
\text { ('Criollos' name) }\end{array}$ & $\begin{array}{l}\text { Orig } \\
\text { in }\end{array}$ & $\begin{array}{l}\text { Part use, Way of preparation and } \\
\text { administration, (Recipe) }\end{array}$ & Application (Therapeutic effect attributed) & $\begin{array}{l}\text { Frequency } \\
(\%)\end{array}$ \\
\hline & & & & Fat /Unprepared / Friction and massages & Eye conditions (applied over the eyelids) & ** \\
\hline Columbidae & $\begin{array}{l}\text { cfr. Leptotila verreauxi } \\
\text { Bonaparte }\end{array}$ & $\begin{array}{l}\text { coiguenec } \quad \text { (yorotí, } \\
\text { yeruti) }\end{array}$ & $\mathrm{N}$ & Fat/ Unprepared/ Friciton and massages & $\begin{array}{l}\text { Socialization and children's behavior (acquisition of gait): } \\
\text { Apply the fat of the yoroti's tail and chest in the baby's waist, } \\
\text { so that they will be able to walk with strength }\end{array}$ & * \\
\hline Falconidae & cfr. Polyborus plancus Miller & $\begin{array}{l}\text { canagaye' lapagaxai } \\
\text { (águila, carancho) }\end{array}$ & $\mathrm{N}$ & Fat/ Unprepared / Friction and massages & Gangrene and severe ulcerations (anti-infectives) & * \\
\hline Mimidae & Mimus triurus Vieillot & calanya' (calandria) & $\mathrm{N}$ & Animal / Roasted / Food intake & Socialization and children's behavior (acquisition of speech) & ** \\
\hline \multirow[t]{2}{*}{ Phalacrocoracidae } & $\begin{array}{l}\text { Phalacrocorax brasilianus } \\
\text { Temmink }\end{array}$ & qoyipe (biguá) & $\mathrm{N}$ & Feather/ Incineration / Inhalation & To treat flu & ** \\
\hline & & & & Fat / Unprepared / Friction and massages & $\begin{array}{l}\text { The fat of its kidney and heart is used for rubbing the chest to } \\
\text { prevent flu }\end{array}$ & ** \\
\hline \multirow[t]{10}{*}{ Phasianidae } & Gallus gallus & olgaxa & I & Eggs /Unprepared/ Poultice & Burns & 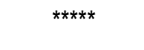 \\
\hline & & & & Eggs/Beverage & To ease birth (oxytoxic) & $* *$ \\
\hline & & & & Fat/ Frictions and massages & Pimples & ** \\
\hline & & & & & Wounds and injuries & * \\
\hline & & & & & $\begin{array}{l}\text { Chagas' disease } \\
\text { (antiinflammatory) }\end{array}$ & $* \star * *$ \\
\hline & & & & & Prevention of flu: rub the chest & ** \\
\hline & & & & & Fever (febrifuge) & $* *$ \\
\hline & & & & & Sprains and twist (anti-inflammatory joint) & ** \\
\hline & & & & & To ease birth. Rub the abdomen to facilitate birth? & ** \\
\hline & & & & Feather/Incineration/ Topic & Navel cicatrizant & * \\
\hline \multirow[t]{2}{*}{ Picidae } & Celeus lugubris Malherbe & nacoyaxa (carpintero) & $\mathrm{N}$ & & $\begin{array}{l}\text { Harbinger of disease and shamanic spirit. When singing near } \\
\text { the house, it announces illness or death in the family. }\end{array}$ & * \\
\hline & $\begin{array}{l}\text { Colaptes spp. : C. } \\
\text { melanochlorus Gmelin; C. }\end{array}$ & chochon (carpintero) & N & & The song is a harbinger of asthma in the family & * \\
\hline
\end{tabular}


Martínez 2013. Use of fauna in the traditional medicine of native Toba (qom) from the Argentine Gran Chaco region: an ethnozoological and conservational approach. Ethnobio Conserv 2:2

\begin{tabular}{|c|c|c|c|c|c|c|}
\hline $\begin{array}{l}\text { CLASS } \\
\text { Family }\end{array}$ & Species & $\begin{array}{l}\text { Local name } \\
\text { ('Criollos' name) }\end{array}$ & $\begin{array}{l}\text { Orig } \\
\text { in }\end{array}$ & $\begin{array}{l}\text { Part use, Way of preparation and } \\
\text { administration, (Recipe) }\end{array}$ & Application (Therapeutic effect attributed) & $\begin{array}{c}\text { Frequenc } \\
(\%)\end{array}$ \\
\hline
\end{tabular}

Psitacidae

Amazona aestiva L.

ele' (loro halador)

N

Feather/ Incineration/ Topic

Earache

Rheidae

Rhea americana Mohring

mañic (suri, ñandú)

N

Fat/Unprepared/ Frictions and massages

headaches

Wounds and injuries

Boils and abscesses (maturative)

Eruptive diseases (chickenpox, measles, others).

vesicles and skin blisters

Sore throat (anti-inflammatory)

Earache

To treat flu. Rub the body to strengthen

joint conditions and muscle aches (anti-arthritic and antiinflammatory)

Sprains and twists (anti-inflammatory joint)

Fat/ Unprepared/ Topic

mouth sores and fires (cicatrizant)

Feather/Incineration/topic

Feather/ Symbolic action

Eggs/Symolic action

Crop / Infusion or decoction/ Beveraje
Earache: roll a cigarette and blow the ashes into the ear canal

Nosebleed (haemostatic)

Snakebites: tie a white feather wing to the bite. The ostrich is the owner of the snake, so no fears him and is his partner.

Socialization and children's behavior: A rogative that

promotes the virtues of suri during adolescence and family

building.

Internal parasites (anthelmintic)

Lunatics, demoniacs or "copchaxaic" (prevention)

Flatulence ( carminative) 
Martínez 2013. Use of fauna in the traditional medicine of native Toba (qom) from the Argentine Gran Chaco region: an ethnozoological and conservational approach. Ethnobio Conserv 2:2

\begin{tabular}{|c|c|c|c|c|c|c|}
\hline $\begin{array}{l}\text { CLASS } \\
\text { Family }\end{array}$ & Species & $\begin{array}{l}\text { Local name } \\
\text { ('Criollos' name) }\end{array}$ & $\begin{array}{l}\text { Orig } \\
\text { in }\end{array}$ & $\begin{array}{l}\text { Part use, Way of preparation and } \\
\text { administration, (Recipe) }\end{array}$ & Application (Therapeutic effect attributed) & $\begin{array}{l}\text { Frequency } \\
(\%)\end{array}$ \\
\hline & & & & & Constipation (laxative) & $*$ \\
\hline & & & & & Stomachache (digestive) & $* *$ \\
\hline & & & & & Pregnancy care and treatment. Retention of pregnancy & $* *$ \\
\hline & & & & & To ease birth (oxytoxic) & $* \star \star *$ \\
\hline & & & & & Treatment of retained placenta & $* \star * *$ \\
\hline Strigidae & Otus choliba Vieillot & qoloxolcoq (lechuzita) & N & & $\begin{array}{l}\text { The song is a harbinger of disease and indicates the } \\
\text { presence of dead spirits }\end{array}$ & * \\
\hline Tinamidae & $\begin{array}{l}\text { Cfr.Crypturellus tataupa } \\
\text { Temminck }\end{array}$ & $\begin{array}{l}\text { so'oỹon } \quad \text { (tordillo, } \\
\text { martineta) }\end{array}$ & N & Legs / Infusion or decoction/ Beverage & $\begin{array}{l}\text { Boil two legs in a kettle and drink the infusion to treat } \\
\text { "incurable cancer" (lesions) of purulent venereal diseases of } \\
\text { women. }\end{array}$ & ** \\
\hline \multirow[t]{3}{*}{ Trochilidae } & $\begin{array}{l}\text { Heliomaster furcifer Shaw } \\
\text { Hylocharis chrysura Shaw } \\
\text { Chlorostilbon aureoventris } \\
\text { Glittering }\end{array}$ & $\begin{array}{l}\text { shimiaxai'chi } \\
\text { shimiaxai'chi late'e } \\
\text { (picaflor, colibri) }\end{array}$ & $\mathrm{N}$ & Nest /Incineration (ash)/ External use (smoke) & Earache & ** \\
\hline & & & & Nest/Incineration/Friction and massages & $\begin{array}{l}\text { Evil-eye. Rub ashes on the "open" head of a child affected by } \\
\text { "ojeadura" }\end{array}$ & ** \\
\hline & & & & Symbolic actions & $\begin{array}{l}\text { Eye conditions. If a parent harms a hummingbird nest or kills } \\
\text { this bird during the pregnancy of his consort, the child } \\
\text { develops conjunctivitis at birth. } \\
\text { See details in Hecht et al. (2008) and Martinez (2010) }\end{array}$ & ** \\
\hline Tyrannidae & $\begin{array}{l}\text { cfr. Euscarthmus } \\
\text { meloryphus }\end{array}$ & pichaqchic & $\mathrm{N}$ & Nest /Incineration (ash)/ External use & Boils and abscesses & * \\
\hline \multicolumn{7}{|l|}{ MAMMALIA } \\
\hline \multirow[t]{2}{*}{ Bovidae } & Bos taurus L. & huaaca (vaca) & I & Manure/Incineration (ash)/ Wash & Acne and facial pimples & * \\
\hline & & & & $\begin{array}{l}\text { Dissolve in } 1 \text { liter of water a tablespoon of dried } \\
\text { cow manure; the supernatant fluid is used to } \\
\text { wash pimples once they were cleaned with soap } \\
\text { and water }\end{array}$ & Pimples & * \\
\hline
\end{tabular}


Martínez 2013. Use of fauna in the traditional medicine of native Toba (qom) from the Argentine Gran Chaco region: an ethnozoological and conservational approach. Ethnobio Conserv 2:2

\begin{tabular}{|c|c|c|c|c|c|c|}
\hline $\begin{array}{l}\text { CLASS } \\
\text { Family }\end{array}$ & Species & $\begin{array}{l}\text { Local name } \\
\text { ('Criollos' name) }\end{array}$ & $\begin{array}{l}\text { Orig } \\
\text { in }\end{array}$ & $\begin{array}{l}\text { Part use, Way of preparation and } \\
\text { administration, (Recipe) }\end{array}$ & Application (Therapeutic effect attributed) & $\begin{array}{l}\text { Frequency } \\
(\%)\end{array}$ \\
\hline & & & & Manure/Incineration (ash)/ Exposed to smoke & $\begin{array}{l}\text { Insect repellent } \\
\text { (Culicidae and Psychodidae) }\end{array}$ & ** \\
\hline & & & & $\begin{array}{l}\text { Bones /Unprepared/ Frictions and massages. } \\
\text { Marrow is used as soap, in regions where spots } \\
\text { occur }\end{array}$ & Skin spots & ** \\
\hline & & & & Blood & $\begin{array}{l}\text { Used to relieve pain and "fever" of the foot. Walk barefoot on } \\
\text { fresh blood }\end{array}$ & * \\
\hline & Capra hircus L. & ketaq (cabra) & I & Fat/ Frictions and massages & Skin blisters & * \\
\hline & & & & & Hit and hematoma & $* * * * *$ \\
\hline & & & & & Muscle pain & *** \\
\hline & & & & $\begin{array}{l}\text { Prepare a cream with goat fat, salt and sawdust } \\
\text { of "palo santo" (Bulnesia sarmientoi) }\end{array}$ & Sprains and twists (anti-inflammatory joint) & $* * * * *$ \\
\hline & & & & $\begin{array}{l}\text { Blood/Fried/Food intake. It gives the child a fried } \\
\text { blood of a newborn animal }\end{array}$ & $\begin{array}{l}\text { Intestinal parasites } \\
\text { (pinworm) }\end{array}$ & * \\
\hline & Ovis aries $\mathrm{L}$. & qagueta (oveja) & I & $\begin{array}{l}\text { Blood/Fried/Food intake. It gives the child a fried } \\
\text { blood of a butchering animal }\end{array}$ & $\begin{array}{l}\text { Intestinal parasites } \\
\text { (pinworm) }\end{array}$ & ** \\
\hline & & & & Hair/ Symbolic action & $\begin{array}{l}\text { To ease birth. Wrap the abdomen of pregnant women in strips } \\
\text { of wool }\end{array}$ & * \\
\hline & & & & & $\begin{array}{l}\text { Pregnancy care. If a pregnant woman wants to conceive a girl } \\
\text { she should use a wool belt. }\end{array}$ & ** \\
\hline \multirow[t]{5}{*}{ Canidae } & $\begin{array}{l}\text { Crysocyon brachyurus } \\
\text { Illeger }\end{array}$ & qa'alac (aguará guazú) & & Fat/Unprepared/Friction and massages & Arthritis and joint conditions (antiarthritic) & * \\
\hline & Canis lupus familiaris $\mathrm{L}$. & pioq (perro) & & Leg/Symbolic action & $\begin{array}{l}\text { Stye. Rub the leg of a puppy on the eye to heal a stye } \\
\text { originated by seeing intercourse between dogs }\end{array}$ & * \\
\hline & & & & Hair/Symbolic action & $\begin{array}{l}\text { To treat toothache arising from taboo violation during } \\
\text { mourning }\end{array}$ & ** \\
\hline & Cerdocyon thous $\mathrm{L}$. & huaxaỹaxa (zorro) & $\mathrm{N}$ & Fat/ Unprepared/ Friction and massages & Muscle pain, especially leg pain & * \\
\hline & & & & Bone/ Milled in water /Beverage & $\begin{array}{l}\text { Scrape the bone of the fox penis and put it in the water of the } \\
\text { kettle to prepare 'mate'. }\end{array}$ & ** \\
\hline
\end{tabular}


Martínez 2013. Use of fauna in the traditional medicine of native Toba (qom) from the Argentine Gran Chaco region: an ethnozoological and conservational approach. Ethnobio Conserv 2:2

\begin{tabular}{|c|c|c|c|c|c|c|}
\hline $\begin{array}{l}\text { CLASS } \\
\text { Family }\end{array}$ & Species & $\begin{array}{l}\text { Local name } \\
\text { ('Criollos' name) }\end{array}$ & $\begin{array}{l}\text { Orig } \\
\text { in }\end{array}$ & $\begin{array}{l}\text { Part use, Way of preparation and } \\
\text { administration, (Recipe) }\end{array}$ & Application (Therapeutic effect attributed) & $\begin{array}{l}\text { Frequency } \\
(\%)\end{array}$ \\
\hline & $\begin{array}{l}\text { Mazama gouazoubira G. } \\
\text { Fischer }\end{array}$ & $\begin{array}{ll}\text { 'imshi, } & \text { niemshe } \\
\text { (guasuncho) }\end{array}$ & $\mathrm{N}$ & Meat and viscera/Infusion or decoction/ beverage & Blood disorders (purifier) & ** \\
\hline & & & & Meat and viscera / A heart infusion or as jerky & Stop menstrual bleeding & ** \\
\hline Cricetidae & Holochilus sp. & chigoxonaxa (rata) & N & Nest/ Symbolic action & $\begin{array}{l}\text { To treat enuresis. The nest of this mouse is burned and ashes } \\
\text { are placed on the abdomen. The nest is also used as a diaper }\end{array}$ & * \\
\hline \multirow[t]{12}{*}{ Dasypodidae } & Dasypus septemcinctus L. & tapinec (mulita) & N & $\begin{array}{l}\text { Fat/Unprepared/ Frictions and massages. } \\
\text { External use }\end{array}$ & Skin blisters & * \\
\hline & & & & & Dog bites & ** \\
\hline & & & & & Pimples & ** \\
\hline & & & & & Burns & * \\
\hline & & & & & Wounds and injuries (cicatrizant) & * \\
\hline & & & & & Earache & ****** \\
\hline & & & & Fat/ Food intake & Asthenia / weakness & ** \\
\hline & Euphractus sexcinctus L. & $\begin{array}{l}\text { napam (mulita, } \\
\text { gualacate, tatú, pichi, } \\
\text { peludo) }\end{array}$ & N & Fat/Unprepared/Topic and external use & Burns & $* * \star$ \\
\hline & & & & & Wounds and injuries & ** \\
\hline & & & & & Earache & $* * * *$ \\
\hline & $\begin{array}{l}\text { Tolypeutes mataco } \\
\text { Desmarest }\end{array}$ & $\begin{array}{l}\text { mogosaxan } \\
\text { (quirquincho bola, tatú } \\
\text { bolita) }\end{array}$ & N & Leather / infusión or decoction / beverage & $\begin{array}{l}\text { Sexually transmitted diseases. It should be drunk while seeing } \\
\text { the planet Venus }\end{array}$ & * \\
\hline & & & & & Vaginal infections (antibiotic, antivenereal) & * \\
\hline Didelphidae & Didelphis albiventris Lund & al (comadreja) & N & Fat/ Unprepared/ Topic & Skin blisters (resolutive) & * \\
\hline Equidae & Equus caballus $\mathrm{L}$. & caaỹo (caballo) & I & Manure / Incineration / Symbolic action & Nosebleeds. Drip the blood on manure to stop bleeding & * \\
\hline
\end{tabular}


Martínez 2013. Use of fauna in the traditional medicine of native Toba (qom) from the Argentine Gran Chaco region: an ethnozoological and conservational approach. Ethnobio Conserv 2:2

\begin{tabular}{|c|c|c|c|c|c|c|}
\hline $\begin{array}{l}\text { CLASS } \\
\text { Family }\end{array}$ & Species & $\begin{array}{l}\text { Local name } \\
\text { ('Criollos' name) }\end{array}$ & $\begin{array}{l}\text { Orig } \\
\text { in }\end{array}$ & $\begin{array}{l}\text { Part use, Way of preparation and } \\
\text { administration, (Recipe) }\end{array}$ & Application (Therapeutic effect attributed) & $\begin{array}{l}\text { Frequency } \\
(\%)\end{array}$ \\
\hline & Equus asinus $\mathrm{L}$. & ashina (burro) & I & Manure / Incineration / Symbolic action & Nosebleeds. Drip the blood on manure to stop bleeding & $* * \star$ \\
\hline & & & & Milk / Food intake & Cough, whooping cough, catarrh & 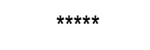 \\
\hline \multirow[t]{3}{*}{ Felidae } & $\begin{array}{l}\text { Oncifelis geoffroyi d'Orbigny } \\
\& \text { Gervais }\end{array}$ & copaic (gato montés) & N & Fat/Unprepared/Friction and massages & Eruptive diseases (chickenpox, measles, others) & $* * *$ \\
\hline & Puma concolor $\mathrm{L}$. & saxuaxaic (león) & $\mathrm{N}$ & Fat/ Unprepared/Friction and massages & Sore throat & ** \\
\hline & & & & & Joint conditions (anti-arthritic and anti-inflammatory) & $* * *$ \\
\hline \multirow[t]{5}{*}{ Hydrochoeridae } & $\begin{array}{l}\text { Hydrochoerus hydrochaeris } \\
\text { L. }\end{array}$ & hualliquiaxai (carpincho) & N & Fat/ Unprepared/Friction and massages & Joint conditions (anti-arthritic) & ** \\
\hline & & & & & Hit and hematoma (anti-inflammatory) & * \\
\hline & & & & Fat/Unprepared/ Beverage or Food intake & Asthma & * \\
\hline & & & & & Bronchial and pulmonary diseases & $* * *$ \\
\hline & & & & $\begin{array}{l}\text { Make a tea mixed with bark of Geoffroea } \\
\text { decorticans and a tablespoon of fat from } \\
\text { capybara, which is drunk twice a day. It also can } \\
\text { be ingested in the form of crackling or drink }\end{array}$ & Tuberculosis & ** \\
\hline Leporidae & Sylvilagus brasiliensis L. & lerema (liebre) & & Leather / Symbolic action & Sleeping newborn (see details in Hecth et al. 2008) & ** \\
\hline Mustelidae & Conepatus chinga Molina & coñim (zorrino) & & Meat / Food intake & Prevention of flu & * \\
\hline \multirow[t]{5}{*}{ Myrmecophagidae } & Myrmecophaga tridactyla L. & potai' (oso hormiguero) & $\mathrm{N}$ & Hair/Incineration (ash)/Topic use & Itching, irritation, rash & ** \\
\hline & & & & Hair and fat / Topic use & $\begin{array}{l}\text { Ashes and fat are applied in mouth sores and fires } \\
\text { (cicatrizant) }\end{array}$ & $* * *$ \\
\hline & & & & Hair /Symbolic action & Sleeping newborn (see details in Hecht et al.,2008) & \\
\hline & & & & Fat/Unprepared/External use & Burns & ** \\
\hline & & & & & Tuberculosis & ** \\
\hline
\end{tabular}


Martínez 2013. Use of fauna in the traditional medicine of native Toba (qom) from the Argentine Gran Chaco region: an ethnozoological and conservational approach. Ethnobio Conserv 2:2

\begin{tabular}{|c|c|c|c|c|c|c|}
\hline $\begin{array}{l}\text { CLASS } \\
\text { Family }\end{array}$ & Species & $\begin{array}{l}\text { Local name } \\
\text { ('Criollos' name) }\end{array}$ & $\begin{array}{l}\text { Orig } \\
\text { in }\end{array}$ & $\begin{array}{l}\text { Part use, Way of preparation and } \\
\text { administration, (Recipe) }\end{array}$ & Application (Therapeutic effect attributed) & $\begin{array}{l}\text { Frequency } \\
(\%)\end{array}$ \\
\hline & & & & & $\begin{array}{l}\text { Severe ulcerations and gangrene. To supplement shamanic } \\
\text { therapy }\end{array}$ & $*$ \\
\hline & & & & $\begin{array}{l}\text { bones/Milled/poultice } \\
\text { fat/friction and massages }\end{array}$ & $\begin{array}{l}\text { To treat broken bones (because the anteater is strong and } \\
\text { does not break ever) (reconstituting bone, resolving) }\end{array}$ & $* \star *$ \\
\hline & & & & Nail/Symbolic action & $\begin{array}{l}\text { Protection from evil: cross two nails on the chest to protect } \\
\text { against injury, disease and evil sent by a shaman ('pi'oxonaq') }\end{array}$ & * \\
\hline \multirow[t]{4}{*}{ Procyonidae } & Nasua nasua (L.) Berg. & coshingo' (coati) & $\mathrm{N}$ & Fat/Unprepared/Friction and massages & $\begin{array}{l}\text { Pimples } \\
\text { (dermatic) }\end{array}$ & * \\
\hline & & & & & Boils and abscesses (disinfectant) & * \\
\hline & & & & & Mycosis & * \\
\hline & Procyon cancrivorus Cuvier & pior'oralo' (mayoblasto) & $\mathrm{N}$ & & Its presence is a harbinger of disease & * \\
\hline Suidae & Sus scrofa domestica L. & $\cos$ (chancho) & I & Fat/ Mixed with onions in wine & To produce alcohol arrest & ** \\
\hline Tapiridae & Tapirus terrestris $\mathrm{L}$. & shipegaqalo (anta, tapir) & N & Nail/Boiled/Beverage & $\begin{array}{l}\text { Ease birth (oxytocic or symbolic action). It is used because } \\
\text { the birth of this animal is very fast }\end{array}$ & ** \\
\hline
\end{tabular}


Table 3. Higher taxonomic categories and their № uses / № of species ratio

\begin{tabular}{|c|c|c|c|}
\hline \multicolumn{2}{|c|}{$\begin{array}{l}\text { Taxonomic Categories } \\
\text { (Group, Phylum and Class) }\end{array}$} & \multicolumn{2}{|c|}{ № uses / № Spp. Ratio } \\
\hline & & Groups & Classes \\
\hline (Invertebrates) & & 1.89 & \\
\hline Phylum Arthropoda & Class Insecta & & 1.69 \\
\hline \multirow[t]{2}{*}{ Phylum Mollusca } & Class Bivalvia & & 5.00 \\
\hline & Class Gastropoda & & 2.00 \\
\hline (Vertebrates) & & 3.08 & \\
\hline \multirow{6}{*}{ Phylum Chordata } & Class Mammalia & & 2.71 \\
\hline & Class Aves & & 3.17 \\
\hline & Class Reptilia & & 5.00 \\
\hline & Class Osteichthyes & & 1.50 \\
\hline & Class Amphibia & & 2.00 \\
\hline & Class Condrichthyes & & 1.00 \\
\hline
\end{tabular}

Figure 3 shows that the families with the greatest number of medicinal species are Apidae for invertebrates, and Bovidae, Dasypodidae, Canidae and Trochilidae for vertebrates, all of them including 3 or 4 species each. Regarding the number of medicinal uses, the families Rheidae, Teiidae, Bovidae, Dasypodidae, Apidae, Myrmecophagidae and Phasianidae are at the top of the list, evidencing the importance of vertebrates (Birds, Mammals and Reptiles).

The importance of Hymenoptera among the insects with medicinal uses (22 species out of 42) was already noted by Costa-Neto (2002) for NE Brazil, while Canids were described among the mammal species most frequently used in zootherapy around the world (Alves et al. 2010). Likewise, the review by Alves et al. (2008) describes the fact that reptiles are among the animal species most used in traditional folk medicine and have been since ancient times.

Regarding applications, Table 4 shows the clear preference for using animal fat $(42 \%)$. The number of applications for the external parts of animals, such as insect cuticles, hides and tegumentary annexes (15\%), i.e. hairs, feathers, nails, shells, rattlesnake, rattles, etc., is much greater than for the internal parts ( $9 \%)$, meat, blood and viscera. Also relevant is the number of uses given to bird nests $(9 \%)$, which in turn is the least extractive application. The preference for animal fats in domestic medicine is apparently a common phenomenon in zootherapy as shown in different previous reports (Bourdy et al. 2004; Alves et al. 2008, 2009; Costa-Neto 1999; Filipov 1997). The popularity of the use of Tupinambis merianae fat, a widespread natural medicine, has been the motive of one of the few studies on the clinical efficacy of animal products for medicinal purposes (Ferreira et al. 2010). 


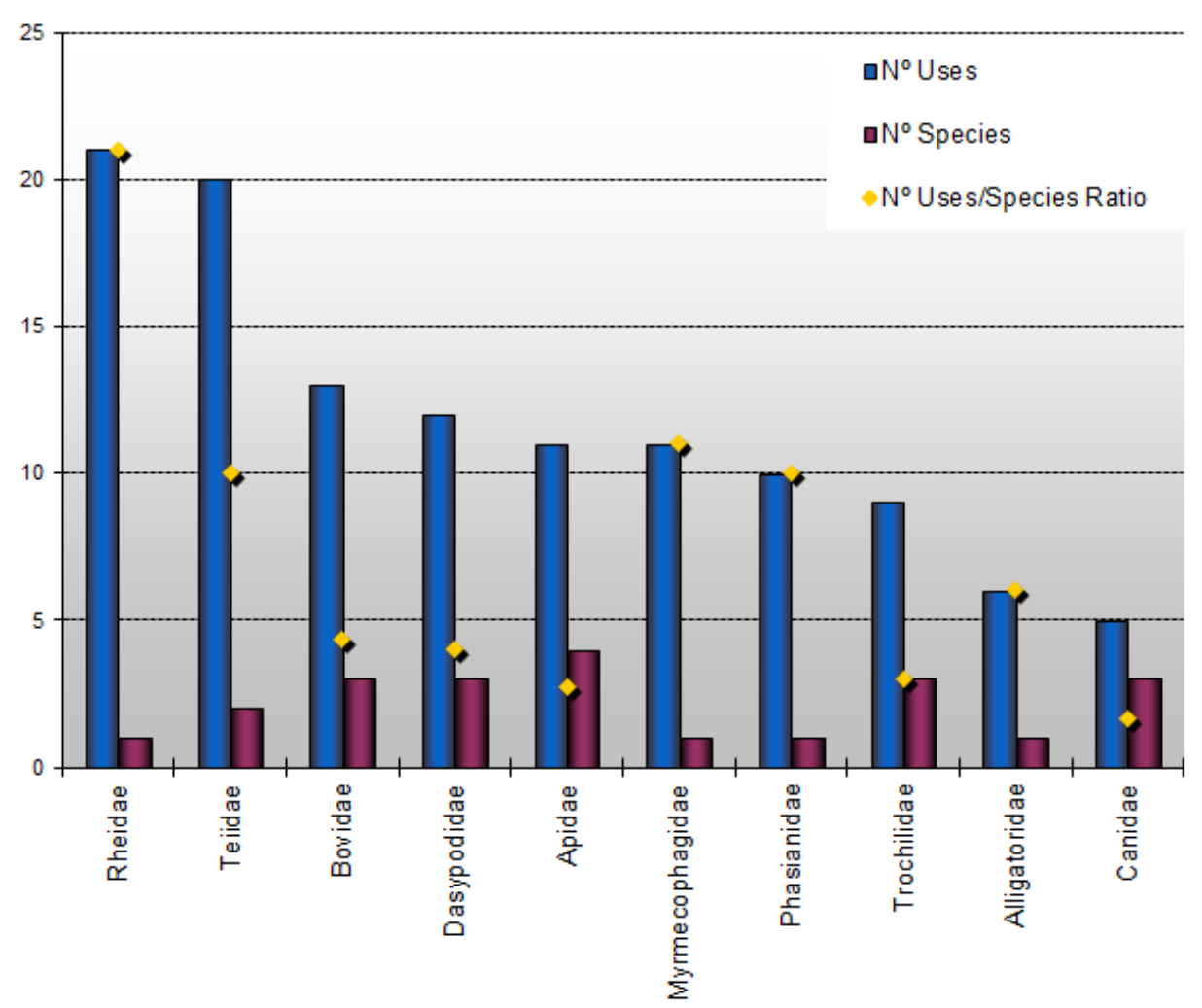

Figure 3. Zoological families with the highest number of species and medicinal uses.

Regarding forms of preparation (Table 5), the direct application of fats is preferred (53\%) as well as the use of the ashes from tegumentary annexes, bones and nests $(21 \%)$. Concerning the forms of administration, external use applications are mostly used (74\%), with frictions and massages being the most common forms for fatty preparations, although topical uses and symbolic actions are also frequent (Table 6). External applications appear to be a specific dominion of the Toba animal pharmacopoeia as opposed to their phytotherapy treatments that mainly uses internal applications as infusions or decoctions (Martínez 2010c).

Table 4. Animal parts used in the traditional medicine practices ordered by decreasing values of frequency of use.

\begin{tabular}{lc}
\hline Animal part & $\begin{array}{c}\text { Frequency } \\
\text { of use }\end{array}$ \\
\hline Fats & 42.13 \\
Cuticles, hides and skin annex (shells, & 15.23 \\
bells, teeth, hair, feathers, nails) & \\
Nests & 9.14 \\
Meat, blood and viscera (swish, brain) & 8.63 \\
Shells and bones (Endo and & 5.08 \\
exoskeletons) & \\
Eggs and milk & 5.08 \\
Whole animal & 4.57 \\
Honey and bees products & 4.57 \\
Manure & 3.05 \\
Cocoons and larvaes & 2.54 \\
\hline
\end{tabular}


Table 5. Form of preparation of animal remedies ordered by decreasing values of frequency of use.

\begin{tabular}{lc}
\hline Form of preparation & $\begin{array}{l}\text { Frequency } \\
\text { of use }\end{array}$ \\
\hline Unprepared & 52.94 \\
Incineration (ash, embers) & 21.32 \\
Infusion or decoction & 15.44 \\
Cocked (boiling, roasted, fried) & 5.88 \\
In solution or macerated & 2.94 \\
Milled & 1.47 \\
\hline
\end{tabular}

Table 6. Way of application of animal remedies ordered by decreasing values of frequency of use. (E: External; I: Internal) (E: External; I: Internal)

\begin{tabular}{lc}
$\begin{array}{l}\text { Way of application } \\
\text { E: External; I:Internal }\end{array}$ & $\begin{array}{l}\text { Frequency } \\
\text { of use }\end{array}$ \\
\hline (E) Friction and massages & 38.38 \\
(E) Topic & 15.68 \\
(E) Symbolic action & 8.65 \\
(E) Inhalation and exposure to & \\
smoke & 2.70 \\
(E) Body gadget & 2.16 \\
(E) Poultices and plasters & 2.16 \\
(E) Washes & 2.16 \\
(E) Eye drops or eye bath & 2.16 \\
(E) Incision & 0.54 \\
(I) Drink & 14.59 \\
(I) Food intake, chewing & 11.89 \\
\hline
\end{tabular}

Considering animals with the highest number of medicinal applications (Figure 4 ), the list is headed by 3 native species (Rhea americana, Tupinambis merianae and Myrmecophaga tridactyla). A broad range of uses is also observed for introduced domestic fauna, as in the case of Gallus gallus, Bos taurus, Capra hircus and Apis mellifera (now wild), demonstrating general agreement between their uses and applications from other Latin American zoo-therapies (Alves and Alves 2011). Likewise, the number of medicinal uses for species like Rhea americana, Caiman latirostris chacoensis, or Tupinambis merianae could have arisen from the interaction with neighboring Criollo communities in Formosa, Corrientes and Santiago del Estero, as evidenced in the current folklore of these groups (Di Lullo 1944). 


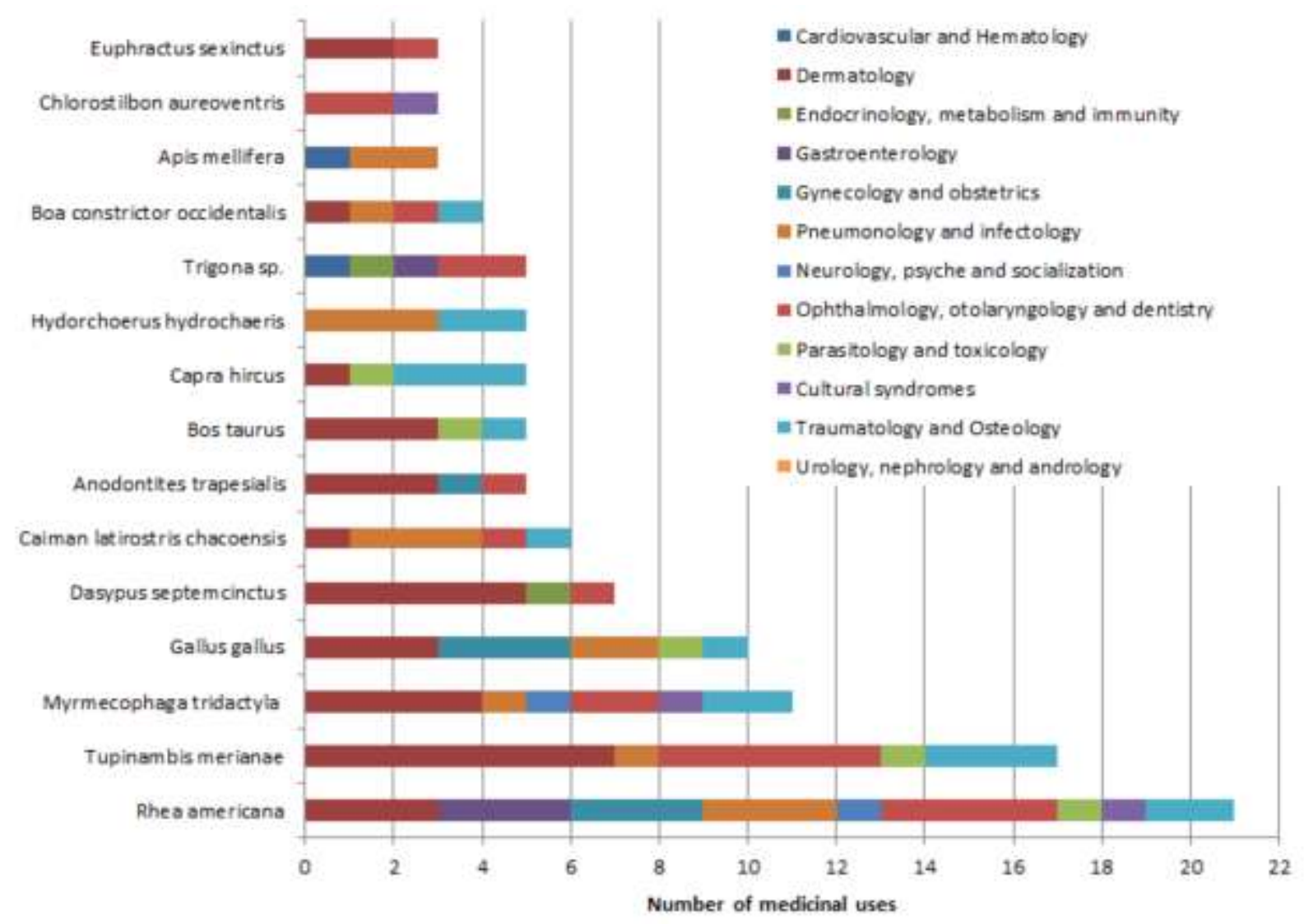

Figure 4. Proportion of medicinal uses in species with the highest number of applications.

On the other hand, the connection between some of these applications and a magical-symbolical aspect cannot be disdained, particularly regarding the representation of these beings in the Toba mythology and cosmology as discussed below. Thus, the strength of the "da'ail'oc" (Caiman latirostris) and "mañic" (Rhea americana), as well as the social and reproductive behavior of the latter, makes them carriers of forces related to the health and progeny of children, evidencing the metaphorical use of these remedies in Toba infants. Similarly, we note, that, for instance, all remedies that encourage speech involve the emission of a sound as in the song of a cricket or "millic" (Grillus argentinus) or as in empty snail shells of "nashiỹo" (Strophocheilus oblongus). Rats or "chigoxonaxa" (Holochilus sp.), of imperceptible excretas, also make up the treatment for maintaining sphincter control. Likewise, hare leather (Sylvilagus brasiliensis) or "ledema lo'oc" is used to help to induce newborn sleep, since hares are regarded as animals with sleepy habits.

In all these or related cases, apart from a potential pharmacological effect, their medical use also involve a sacred power, i.e., a symbolical efficiency (Le Breton 1995). The ethnomedical context within which each of the species is used has been previously described and escapes the purpose of this study. More details on the cultural significance, metaphorical value and implicit therapeutic criteria of the applications of these natural pharmacopoeia can be found in our previous contributions (Hecht et al. 2008; Martinez 2007, 2010b,c; Martínez and Barboza 2010).

Table 7 shows that animal pharmacopoeia provides a great number of uses, especially regarding skin afflictions (22\%), eye, ear and mouth disorders $(21 \%)$, pneumonological or infectological situations (12\%) and osteo-arthro-muscular 
problems (11\%). It also shows that the highest consensus is regarding the choice of remedies for gastroenterological $\left(F_{I C}=0.92\right)$, dermatological $\left(F_{I C}=0.90\right)$ and pneumonological or infectological $\left(F_{I C}=0.90\right)$ problems, evidencing a selection of species based on very defined and precise criteria for these health areas instead of a random selection. As an example, and as described in a specific study on Toba skin affections, the use of ashes from the shell of the mollusk Anodontites trapesialis (Unionidae) is first on the list of animal pharmacopoeia for its popularity as a cicatrizant, followed by the use of Gallus gallus fat as resolutive and Chunga burmeisteri manure as maturative (Martínez and Barboza 2010).

On the contrary, the treatment of cultural syndromes $\left(F_{I C}=0.61\right)$ and urological, nephrological and andrological disorders $\left(F_{I C}=0.70\right)$, as well as metabolic, endocrine and immunological problems $\left(F_{I C}=0.75\right)$, have the lowest levels of consensus. The low consensus regarding metabolic affections and cultural syndromes associated to scarce use reports are probably due, in the former case, to a poor and imprecise knowledge of specific applications for the areas, and in the latter, to the exclusivity of certain cultural information that only a few individuals bear and do not reveal indiscreetly, and that predominantly involve symbolical applications.

The accordance of our data with the results of Alves et al. (2009) for the semiarid region of Pernambuco is noticeable regarding the high level of informant consensus on the use of specific animal remedies for skin problems and respiratory and digestive diseases, evidencing a widespread valorization of zootherapy in this sphere of folk medicine.

Table 7. Quantitative analysis of the categories of medicinal uses: Number and percentage of species, uses and use reports, number of species / number of uses ratio and Informant Consensus Factor (Fic) (According to decreasing values of Fic; Total species: 72; Total Uses reports: 199).

\begin{tabular}{|c|c|c|c|c|c|c|c|c|}
\hline $\begin{array}{l}\text { Medicinal Uses } \\
\text { Categories }\end{array}$ & $\begin{array}{l}\text { No } \\
\text { species } \\
\text { (Nt) }\end{array}$ & $\begin{array}{l}\% \\
\text { species }\end{array}$ & $\begin{array}{l}\text { № } \\
\text { Uses }\end{array}$ & $\%$ Uses & $\begin{array}{l}\text { Uses } \\
\text { reports } \\
\text { (Ur) }\end{array}$ & $\begin{array}{l}\% \text { from } \\
\text { the } \\
\text { total Ur }\end{array}$ & $\begin{array}{l}\text { № } \\
\text { Uses/ } \\
\text { № Spp } \\
\text { ratio }\end{array}$ & Fic \\
\hline Gastroenterology & 4 & 3.08 & 8 & 4.02 & 37 & 3.93 & 2.00 & 0.92 \\
\hline $\begin{array}{l}\text { Pneumonology and } \\
\text { infectology }\end{array}$ & 14 & 10.77 & 24 & 12.06 & 130 & 13.80 & 1.71 & 0.90 \\
\hline Dermatology & 19 & 14.62 & 44 & 22.11 & 178 & 18.90 & 2.32 & 0.90 \\
\hline $\begin{array}{l}\text { Traumatology and } \\
\text { Osteology }\end{array}$ & 14 & 10.77 & 22 & 11.06 & 121 & 12.85 & 1.57 & 0.89 \\
\hline $\begin{array}{l}\text { Neurology, psyche } \\
\text { and socialization }\end{array}$ & 10 & 7.69 & 10 & 5.03 & 81 & 8.60 & 1.00 & 0.89 \\
\hline $\begin{array}{l}\text { Gynecology and } \\
\text { obstetrics }\end{array}$ & 12 & 9.23 & 18 & 9.05 & 89 & 9.45 & 1.50 & 0.88 \\
\hline $\begin{array}{l}\text { Ophthalmology, } \\
\text { otolaryngology and } \\
\text { dentistry }\end{array}$ & 26 & 20.00 & 42 & 21.11 & 201 & 21.34 & 1.62 & 0.88 \\
\hline $\begin{array}{l}\text { Parasitology and } \\
\text { toxicology }\end{array}$ & 9 & 6.92 & 9 & 4.52 & 46 & 4.88 & 1.00 & 0.82 \\
\hline $\begin{array}{l}\text { Cardiovascular and } \\
\text { Hematology }\end{array}$ & 3 & 2.31 & 3 & 1.51 & 10 & 1.06 & 1.00 & 0.78 \\
\hline $\begin{array}{l}\text { Endocrinology, } \\
\text { metabolism and } \\
\text { immunity }\end{array}$ & 3 & 2.31 & 3 & 1.51 & 9 & 0.96 & 1.00 & 0.75 \\
\hline $\begin{array}{l}\text { Urology, nephrology } \\
\text { and andrology }\end{array}$ & 4 & 3.08 & 4 & 2.01 & 11 & 1.17 & 1.00 & 0.70 \\
\hline $\begin{array}{l}\text { Cultural syndromes } \\
\text { (Non-organic } \\
\text { illnesses) }\end{array}$ & 12 & 9.23 & 12 & 6.03 & 29 & 3.08 & 1.00 & 0.61 \\
\hline
\end{tabular}


According to the percentage of Ur shown in Table 8, the species with the highest degree of consensus and popularity for the Tobas are Rhea americana, Tupinambis merianae, Gallus gallus, Capra hircus, Myrmecophaga tridactyla, Anodontites trapesialis, Dasypus septemcinctus and Caiman latirostris chacoensis. Considering the $\mathrm{RI}$, the results once again include species like Rhea americana $(\mathrm{RI}=$ $100)$, Tupinambis merianae $(\mathrm{RI}=72.22)$ and Myrmecophaga tridactyla $(\mathrm{RI}=61.11)$. Moreover, this index highlights the importance of Trigona sp. $(\mathrm{RI}=36.11)$ and Boa constrictor occidentalis $(\mathrm{RI}=33.33)$ and places them above the importance of other domestic species with higher values of Ur like Capra hircus or Bos taurus both widely used in Latin American pharmacopoeias.

Table 8 shows how RI, ECV and CS values are combined for each of the medicinal animal species and integrated inside ILCP. The value of ECV comprehends many aspects. For example, the provision of meat from hunted animals is still a common and relatively frequent Toba practice, as for great part of the rural population of the Gran Chaco. Arenas (2003) described that hunting is a means for supplying meat to the staple carbohydrate-based diet (flour, rice, noodles, polenta) and contributes to the subsistence of communities that generally do not have a basic or secure income. According to Altrichter (2006), small species of mammals constitute the main source of wild meat in terms of frequency and biomass for the Gran Chaco mestizo, as observed for the Toba population of the region. The species that are most appreciated for their meat are "suri" (Rhea americana), small deer or "corzuela" (Mazama gouazoubira) and "armadillos" or edentates (Dasypus septemcinctus, Euphractus sexcinctus and Tolypeutes matacus). The latter are particularly hunted during the cold season for their rich fatty content. Although Altrichter (2006) points out that the medicinal use of animals does not generally motivate hunting the species per se, our observations show the contrary in more than one case. This is particularly evident for species like Hydrochoerus hydrochaerus, Tupinambis merianae, Boa constrictor occidentalis, among others, whose fats are highly esteemed remedies for the natives. In this sense we agree with Alves et al. (2010) who consider that the medicinal use of animals generates an additional threat and must be taken into account together with other anthropogenic pressures.

On the other hand, certain felines (Oncifelis geoffroyi, Puma concolor), foxes (Cerdocyon thous), and reptiles (Boa constrictor occidentalis, Caiman latirostris and Tupinambis merianae) of the Gran Chaco were historically threatened by commercial hunting for their hides until important restrictions were made reducing the market and practically eradicating their commercialization (Arenas 2003). Furthermore, the illegal commercialization of wildlife is not a significant income for most of the natives who only occasionally sell parrots (Amazona aestiva) and other animals like beetles to animal collectors or as pets.

Regarding the ecological importance, species like Rhea americana, Hydrochoerus hydrochaeris, and Euphractus sexcinctus are important for their taxonomic singularity because they are monotypic genera and/or families. In other cases, they play a key role in local ecosystems and their reduction or disappearance would cause important environmental alterations as in the case of Puma concolor, Crotalus durissus terrificus, and others.

Another aspect to be considered for any species conservation plan is its sociocultural and mythical-religious significance. The use of animals in native medicine transcends mere zootherapy, and involves, for example, the use of magical 
amulets (Vuoto 1999), performing symbolical healing actions, or using animals as shamanistic auxiliaries that send and/or heal diseases by the transgression of taboos (Martínez 2010a,b). Toba cosmology and religion is filled with sacrality and power, as well as by a series of interdictions and fears regarding the use and exploitation of species. Thus, it is common for animals to be subdued or associated to a theophany, powerful entity, master or guardian, who are the custodians of these non-human beings (Miller 1979; Terán 2000; Ruiz Moras 2001). The most common reference is their belief in the power of "No'ouet", hierophany or a paradigm of the powerful that is responsible for terrestrial species and the forest in general, and is also the initiator of shamans (Cordeu 1969/70; Tola 2001; Wright 1984, 2005). Other deities or mythological animals in their cosmology have different degrees of relevance and influence (Terán 1994, 1998a,b, 2000; Terán 2006). Hence, animism and anthropomorphism are an inherent feature of the Toba cosmovision of the animal world, as expressed by their stories and myths that evidence their significance in everyday life. A brief analysis on the profuse mythographical collection and narrations provided by Wilbert and Simoneau (1982) and Terán (1994) for Tobas shows the diversity of motives for which some of the species in this study are frequently mentioned. Some of these topics are: hierarchies and power relations, kinds of kings (the giant, speaking father of ostrich "mañic", the father and mother of owl "qoloxolcoq", the father of iguanas "qolliguesaq", the father of coati "coshingo"); animals representing a culture hero or trickster (fox "huaxaŷaxa", armadillos "napam" and "tapinec", chuña "lashenec" and lizards); transformation of animals to persons or vice versa (anteater "potai", capybara "hualliquiaxai", chuña "lashenec", armadillos "napam" and "tapinec", deers "ñi'imshi", caiman "da'ail'oc"); stories about animal parts or products that cure diseases (iguanas "qolliguesaq" and rabbit fat); acquisition of magic and shamanic powers (iguana "qolliguesaq"); animal magicians, establishment of animal haunt (coati "coshingo"); friendship, enmity and marriage among animals (black vulture "canagaye" and bigua "qoyipe"); origin of constellations and stars from animals and other notions of ethnoastronomy (ostrich "mañic"); origination of cosmogonies and other cataclysms (fox "huaxaŷaxa", armadillos "napam" and "tapinec"; rainbow boa "qemoxonalo").

Regarding the CS, two of the species used in Toba zootherapy, Myrmecophaga tridactyla and Boa constrictor occidentalis, have been nationally reported as "endangered species" and the second is also included in the CITES I list. These species are also among the first in RI based on the local medicinal applications attributed by the natives. Other species heading the list of priorities for local conservation that are threatened and or listed in CITES II are Rhea americana, Tupinambis rufescens, Chelonoidis spp., Caiman latirostris chacoensis, Oncifelis geoffroyi, Cerdocyon thous, and Tapirus terrestris. Although the medicinal use of species like Hydrochoerus hydrochaeris, Oncifelis geoffroyi, Cerdocyon thous, Tapirus terrestris, Tolypeutes mataco and Puma concolor are very restricted with low values of $\mathrm{Rl}$, their ecological and cultural relevance and their conservation status places them among the first fifteen species of the local conservation priority ranking.

On the other hand, some species of invertebrates - as Trigona sp., Pomacea sp., Nasutitermes sp., and Anodontites trapesialis - that are relevant from an ethnomedical point of view $(\mathrm{RI})$, but to a lesser degree in the ecological cultural aspect, present values of ILCP that are lower than the mean of all the species because they lack references regarding their CS. Despite this, and as discussed below, their importance and role in the fauna resources of the area must not be undermined. 
Table 8. Uses reported (Ur), Relative importance (RI), and Conservation priorities of animal species ordered by decreasing values of ILCP. Criterion for assigning numerical categories according to Table 1) (w/d: without document)

\begin{tabular}{|c|c|c|c|c|c|c|}
\hline SPECIES & Ur & $\mathbf{R} \mathbf{R}$ & $\begin{array}{c}\text { Category } \\
\text { of Relative } \\
\text { Importanc } \\
\mathbf{e} \\
(\mathbf{R I})\end{array}$ & $\begin{array}{l}\text { Category } \\
\text { of } \\
\text { Ecological } \\
\text { and } \\
\text { Cultural } \\
\text { Value } \\
\text { (ECV) }\end{array}$ & $\begin{array}{l}\text { Category } \\
\text { of } \\
\text { Conservati } \\
\text { on Status } \\
\text { (CS) }\end{array}$ & $\begin{array}{l}\text { Index of } \\
\text { Local } \\
\text { Priority } \\
\text { (ILCP) }\end{array}$ \\
\hline Rhea americana & 9.98 & 100.00 & 5 & 5 & 4 & 12.67 \\
\hline Myrmecophaga tridactyla & 4.88 & 61.11 & 4 & 4 & 5 & 10.14 \\
\hline Tupinambis merianae & 8.92 & 72.22 & 5 & 5 & 3 & 9.51 \\
\hline Boa constrictor occidentalis & 1.70 & 33.33 & 3 & 4 & 5 & 7.60 \\
\hline Tupinambis rufescens & 1.17 & 19.44 & 2 & 5 & 4 & 5.07 \\
\hline $\begin{array}{l}\text { Chelonoidis spp. (C. chilensis / } \\
\text { C. carbonaria) }\end{array}$ & 1.06 & 19.44 & 2 & 4 & 4 & 4.06 \\
\hline Caiman latirostris chacoensis & 3.50 & 30.56 & 2 & 4 & 4 & 4.06 \\
\hline Hydrochoerus hydrochaeris & 2.12 & 25.00 & 2 & 5 & 3 & 3.80 \\
\hline Oncifelis geoffroyi & 0.64 & 8.33 & 1 & 5 & 4 & 2.53 \\
\hline Cerdocyon thous & 0.53 & 16.67 & 1 & 5 & 4 & 2.53 \\
\hline Tapirus terrestris & 0.32 & 8.33 & 1 & 4 & 4 & 2.03 \\
\hline Tolypeutes mataco & 0.42 & 16.67 & 1 & 5 & 3 & 1.90 \\
\hline Puma concolor & 1.38 & 16.67 & 1 & 5 & 3 & 1.90 \\
\hline Gallus gallus & 7.11 & 47.22 & 3 & 2 & 2 & 1.52 \\
\hline Euphractus sexcinctus & 1.80 & 19.44 & 2 & 3 & 2 & 1.52 \\
\hline Dasypus septemcinctus & 4.46 & 30.56 & 2 & 3 & 2 & 1.52 \\
\hline Amazona aestiva & 0.42 & 11.11 & 1 & 3 & 4 & 1.52 \\
\hline Conepatus chinga & & & 1 & 3 & 3 & 1.14 \\
\hline Phalacrocorax brasilianus & 0.64 & 11.11 & 1 & 4 & 2 & 1.01 \\
\hline Otus choliba & 0.21 & 8.33 & 1 & 2 & 4 & 1.01 \\
\hline Mazama gouazoubira & 0.64 & 16.67 & 1 & 4 & 2 & 1.01 \\
\hline Hylocharis chrysura & 0.96 & 19.44 & 2 & 2 & 2 & 1.01 \\
\hline Heliomaster furcifer & 0.96 & 19.44 & 2 & 2 & 2 & 1.01 \\
\hline Crysocyon brachyurus & 0.21 & 8.33 & 1 & 2 & 4 & 1.01 \\
\hline Chlorostilbon aureoventris & 0.96 & 19.44 & 2 & 1 & 4 & 1.01 \\
\hline Procyon cancrivorus & 0.21 & 8.33 & 1 & 2 & 3 & 0.76 \\
\hline Nasua nasua & 0.64 & 13.89 & 1 & 2 & 3 & 0.76 \\
\hline Mimus triurus & 0.32 & 8.33 & 1 & 3 & 2 & 0.76 \\
\hline Mimus saturninus & 0.32 & 8.33 & 1 & 3 & 2 & 0.76 \\
\hline Hydrodynastes gigas & 0.21 & 8.33 & 1 & 3 & 2 & 0.76 \\
\hline Crotalus durissus terrificus & 0.32 & 8.33 & 1 & 2 & 3 & 0.76 \\
\hline Coragyps atratus & 0.64 & 16.67 & 1 & 3 & 2 & 0.76 \\
\hline Chunga burmeisteri & 1.17 & 8.33 & 1 & 3 & 2 & 0.76 \\
\hline cfr. Leptotila verreauxi & 0.21 & 8.33 & 1 & 3 & 2 & 0.76 \\
\hline Apis mellifera & 1.59 & 19.44 & 2 & 3 & 1 & 0.76 \\
\hline Sylvilagus brasiliensis & 0.32 & 8.33 & 1 & 2 & 2 & 0.51 \\
\hline Scaptotrigona sp. & 2.02 & 11.11 & 1 & 4 & 1 & 0.51 \\
\hline Colaptes melanolaimus & 0.21 & 8.33 & 1 & 2 & 2 & 0.51 \\
\hline
\end{tabular}




\begin{tabular}{|c|c|c|c|c|c|c|}
\hline Colaptes melanochlorus & 0.21 & 8.33 & 1 & 2 & 2 & 0.51 \\
\hline cfr. Polyborus plancus & 0.21 & 8.33 & 1 & 2 & 2 & 0.51 \\
\hline cfr. Crypturellus tataupa & 0.32 & 8.33 & 1 & 2 & 2 & 0.51 \\
\hline Celeus Iugubris & 0.21 & 8.33 & 1 & 2 & 2 & 0.51 \\
\hline Rhinella spp. & 1.38 & 11.11 & 1 & 2 & 2 & 0.51 \\
\hline Trigona sp. & 2.02 & 36.11 & 3 & 1 & 1 & 0.38 \\
\hline w/d Plebeia spp.? & 0.32 & 8.33 & 1 & 3 & 1 & 0.38 \\
\hline Serrasalmus sp. & 0.42 & 8.33 & 1 & 3 & 1 & 0.38 \\
\hline Prochilodus platensis & 0.74 & 16.67 & 1 & 3 & 1 & 0.38 \\
\hline $\begin{array}{l}\text { Polistes spp. (Polistes cfr. } \\
\text { canadensis and others) }\end{array}$ & 0.96 & 5.56 & 1 & 3 & 1 & 0.38 \\
\hline Pomacea canaliculata & 1.06 & 22.22 & 2 & 1 & 1 & 0.25 \\
\hline Nasutitermes sp. & 1.91 & 19.44 & 2 & 1 & 1 & 0.25 \\
\hline Holochilus sp. & 0.21 & 8.33 & 1 & 1 & 2 & 0.25 \\
\hline Gryllus argentinus & 2.02 & 8.33 & 1 & 2 & 1 & 0.25 \\
\hline Equus caballus & 0.21 & 8.33 & 1 & 1 & 2 & 0.25 \\
\hline Didelphis albiventris & 0.21 & 8.33 & 1 & 1 & 2 & 0.25 \\
\hline cfr. Euscarthmus meloryphus & 0.32 & 8.33 & 1 & 1 & 2 & 0.25 \\
\hline Capra hircus & 5.10 & 30.56 & 2 & 1 & 1 & 0.25 \\
\hline Bos taurus & 1.91 & 25.00 & 2 & 1 & 1 & 0.25 \\
\hline Anodontites trapesialis & 4.67 & 19.44 & 2 & 1 & 1 & 0.25 \\
\hline Sus scrofa domestica & 0.32 & 8.33 & 1 & 1 & 1 & 0.13 \\
\hline Strophocheilus oblongus & 2.66 & 8.33 & 1 & 1 & 1 & 0.13 \\
\hline Scapteriscus borelli & 2.02 & 8.33 & 1 & 1 & 1 & 0.13 \\
\hline Potamotrygon sp. & 0.21 & 8.33 & 1 & 1 & 1 & 0.13 \\
\hline Ovis aries & 0.93 & 16.67 & 1 & 1 & 1 & 0.13 \\
\hline Oiketicus kirbyi & 0.42 & 8.33 & 1 & 1 & 1 & 0.13 \\
\hline Equus asinus & 2.44 & 16.67 & 1 & 1 & 1 & 0.13 \\
\hline $\begin{array}{l}\text { Not determined (Lepidoptera } \\
\text { chrysalis) }\end{array}$ & 0.42 & 13.89 & 1 & 1 & 1 & 0.13 \\
\hline $\begin{array}{l}\text { Coptoteryx argentina, } \\
\text { Stagmatoptera hyaloptera }\end{array}$ & 0.21 & 8.33 & 1 & 1 & 1 & 0.13 \\
\hline Canis lupus familiaris & 0.53 & 11.11 & 1 & 1 & 1 & 0.13 \\
\hline Atta vollenweideri & 0.64 & 8.33 & 1 & 1 & 1 & 0.13 \\
\hline w/d Dorymyrmex exsanguis? & & & 1 & 1 & 1 & 0.13 \\
\hline Not determined (Cicadidae) & 0.42 & 8.33 & 1 & 1 & 1 & 0.13 \\
\hline
\end{tabular}

In all, $30 \%$ of the species used for zootherapy were categorized with levels 3 , 4 and 5, whether vulnerable, threatened or in danger, or in categories I and II of CITES. Similar values of threatened animals were found in other studies, including $30 \%$ of the animal pharmacopoeia of NE Brazil (Costa-Neto 1999), 25\% for canids (Alves et al. 2010) and 53\% for reptiles (Alves et al 2008), both worldwide estimations. However, it is only fair to point out that contrary to studies in other regions of Latin America, we did not observe the commercialization of animal medicinal products among the Tobas, indicating that their recollection is merely restricted to a domestic use and in many cases subordinated to other needs and practices such as food.

Taking the above into account, and according to the perception and uses of the Tobas from the Gran Chaco region, the following ten local species must be prioritized: one bird (Rhea americana), five reptiles (Boa constrictor occidentalis, 
Tupinambis merianae, Tupinambis rufescens, Chelonoidis spp., Caiman latirostris chacoensis) and four mammals (Myrmecophaga tridactyla, Hydrochoerus hydrochaeris, Oncifelis geoffroyi and Cerdocyon thous).

A simple comparison of the Toba indigenous pharmacopoeia with that of other ethnic groups from the Gran Chaco and other regions of Latin America evidences the recurrence of the use of certain species and noticeable coincidences in some of their applications. Thus, the use of Boa constrictor occidentalis, Tupinambis rufescens, Tupinambis merianae, Caiman latirostris chacoensis, Oncifelis geoffroyi, Hydrochoerus hydrochaeris, Mirmecophaga tridactyla and Rhea americana is similar to that of the Pilagá and Toba-Pilagá of Formosa (Filipov 1997; Arenas 2000), evidencing a regional pattern of use and a fluid interethnic exchange of knowledge. Particularly, species like Tupinambis merianae and Rhea americana would seem to adopt a panacean status among the different Chaco groups given the wide range of ailments for which they are used and the variety of their forms of use.

Similarities are also observed in even more geographically and linguistically distant ethic groups. More than $50 \%$ of the species and great part of the applications used in zootherapy by the Tsimane' Amerindian of the Bolivian rain forest and by the Izoceño-Guaraníes or Chiriguanos of the Bolivian Chaco are also found in the Toba animal pharmacopoeia (Apaza et al. 2003; Bourdy et al. 2004). Another example is the relevance of products originated from Tupinambis merianae and Tupinambis teguixin, indicated for the treatment of 8 and 18 conditions respectively, whereas caiman fat (Caiman latirostirs) is still used in Brazilian rural and urban communities for treating rheumatism Alves et al. (2008, 2009). Likewise, Alves and Alves (2011) report, within the framework of Latin America zootherapy, that the products obtained from Tupinambis merianae and Boa constrictor were prescribed to treat near 30 conditions, each one, revealing the amplitude of this pattern of use, probably related to ancient or colonial times. Furthermore, in a review on the use of 14 canids in traditional medicine, Alves et al. (2010) describe a great diversity of uses for Brazil and Bolivia, some of which coincide with applications described by the Tobas.

On the other hand, and despite the lack of information regarding the CS of invertebrates and their inferior ECV compared to vertebrates, these resources are not to be disdained from a symbolical and ethnopharmacological point of view, particularly in species that present widely used applications in different ethnic groups. For example, insects of the Atta, Apis, Plebeia, Trigona, Gryllus and Nasutitermes genera are part of the 42 insects used in folk remedies in Northeast Brazil (CostaNeto 2002), with noticeable coincidences in their medicinal applications as in the case of Gryllus domesticus for children with difficulties or delays in speech development, or the ophthalmological, bucopharingeal and/or pectoral use of hymenopteran honey and other products. This shows the need to further the studies on the medicinal use of insects and insect-derived products that apparently present a very specific pattern of applications, many of which could become potential sources of drugs due to their promising results on/implications for human health, as in the antibiotic activity of the natural products of a species of Nasutitermes genus (Coutinho et al. 2009; Dossey 2010). The study of products related to hymenopteran apiculture and meliponiculture deserves special attention due to the current use of these activities for the subsistence of Tobas and other ethnic groups and farmers of Argentina (Arenas 2003; Zamudio et al. 2010).

To summarize, we can mention the fact that medicinal fauna in Gran Chaco region is based on wild animals, including endangered species, demonstrating remarkable coincidences with ethnomedicines from other Latin American countries. 


\section{Conclusions}

The great wealth of genetic resources and the complex cultural diversity of the Gran Chaco region here presented involve an adaptation process of its ethnic groups, generating an invaluable local knowledge and a medical system that include extensive information on animal uses. Despite the difficulties found in the access to modern biomedical services, the zootherapy "qom" acquires an intrinsic value because of the multiple ways and criteria of uses of the remedies, revealing the existence of a consistent and structured ethnomedicine. A deep understanding of the cultural context of the traditional use of Toba animal therapies seems to be central for elucidating their potential impact not only in public health, but also in local conservation.

Our results show that of the wide range of species used in Toba zootherapy, an important number of reptiles, mammals and birds appreciated for their medicinal applications, cultural significance and other uses, are included in lists of threatened or endangered species for Argentina. Even though the Gran Chaco is particularly affected by structural environmental issues (deforestation and fragmentation of natural environments, expansion of the agricultural frontier, non-sustainable hunting and wildlife trade), the knowledge, use, significance and cultural value of the local fauna for this ethnical group is relevant, as it is a valuable tool for developing conservation strategies. The implementation of wildlife conservation actions that have no negative effects on the lifestyle of local communities, but instead consider and include them, are one of the challenges that must be taken into account when planning them.

The present study on Toba zootherapy not only evidences the actual use of animals in their medical practices, but also the way these natives see and consider themselves regarding their alterity, in this case with animals. Tobas believe that animals have their own spiritual principles enabling them to have interpersonal relations, which undoubtedly influences everyday hunting, fishing and/or gathering practices and in turn affects animal conservation. Without necessarily agreeing with the romantic concept that the Toba indigenous practices are fundamentally ecological as proposed by Miller (1979), it is fair to point out that animistic representations and the anthropomorphization of the animal world are valuable aspects for carrying out sustainable wildlife management with these communities. We agree with Chan (2012) that encouraging anthropomorphism (attributing human characteristics to non-human animals) can help conservation biologists develop more empathy towards target species. We do not pretend, as warned by Arenas (2003), to idealize the relationship between natives and their environment. Moreover, natives are not exempt from making extractive and exploitive use of natural resources nor are they oblivious to the installation of a capitalist form of life, which in more than one case requires monitoring the use of medicines, meat or other animal products, especially for threatened or endangered species as the ones mentioned in this study. Likewise, we must point out that specialists with knowledge on the specificity of these ethnomedical practices are becoming less frequent, and obtaining them is becoming more difficult due to environmental and cultural changes. Therefore, the implementation of inadequate use and management norms would imply the risk of reducing their cultural value, fomenting the lack of intergenerational transmission of traditional uses and hence extinguishing experience by disuse. This situation is observed among Toba communities that have migrated to large cities far away from their native forest, where the new generations have no idea of the species and 
applications used and only the memory of the older people, who at some point were hunters, survives.

Therefore, the ethnozoological perspective of this study provides an integral view of social and ecological elements for the protection of species on a regional scale, which is also methodologically viable for studies in other regions and ethnic groups. The local conservation priorities presented orient the task of zoologists and ecologists towards a sustainable regulation and/or management of species. Finally, they allow choosing premises that can be focused on by sensibilization, interpretation, intercultural and environmental educational tasks in order to mitigate the harmful effects of extractive activities, overexploitation and reduction of the animal and cultural diversity of the Argentine Chaco.

\section{Acknowledgements}

We are extremely grateful to the Toba community of Río Bermejito (Paraje El Colchón) for granting the author their valuable time and information, as well as the kind hospitality of the families, inhabitants and institutions that really facilitated this work. We are also thankful to Lic. Pastor Arenas (CONICET) for his constant advice during this study, Biól. Agustín Zarco for his valuable guidelines, as well as to the specialists that identified, oriented, or confirmed the identifications of the species: Dr. Liliana Buffa and Dr. Claudio Sosa (Insecta); Dr. A. Ceballos (Unionidae). The author would like to thank Catriona Kirkwood and Carolina Mosconi for helping with the English version. The present study was carried out as part of the ANPCyT/FONCyT Pict 1951 and 1612 projects. Conicet supported the work of the author.

\section{References}

Alonso-Castro A, Carranza-Álvarez C, Maldonado-Miranda JJ, Jacobo-Salcedo MR, Quezada-Rivera DA, Lorenzo-Márquez $H$, Figuera-Zúñiga LA, FernándezGalicia, Ríos-Reyes NA, León-Rubio de MA, Rodríguez-Gallegos V, MedellínMilán P. (2011) Zootherapeutic practices in Aquismón, San Luis Potosí, México. Journal of Ethnopharmacology 138: 233-237.

Adámoli J, Sennhauser E, Acero JM, Rescia A (1990) Stress and Disturbance: vegetation dynamics in the dry Chaco region of Argentina. Journal of Biogeography 17:491-500.

Altrichter M (2006) Wildlife in the life of local people of the semi-arid Argentine

Chaco. Biodiversity and Conservation 15:2719-2736.

Alves RRN (2009) Fauna used in popular medicine in Northeast Brazil. Journal of Ethnobiology and Ethnomedicine 5:1.

Alves RRN (2012) Relationship between Fauna and People and the Role of Ethnozoology in Animal Conservation. Ethnobiology and Conservation 1:2.

Alves RRN, Albuquerque UP (2012) Animals as a Source of Drugs: Bioprospecting and Biodiversity Conservation. In: Alves RRN, Rosa IL (eds) Animals in Traditional Folk Medicine: Implications for conservation. 1 ed. Springer-Verlag, Berlin Heidelberg, pp. 67-89. 
Alves RRN, Alves HN (2011) The faunal drugstore: Animal-based remedies used in traditional medicines in Latin America. Journal of Ethnobiology and Ethnomedicine 7:9.

Alves RRN, Rosa IL (2006) From cnidarians to mammals: the use of animals as remedies in fishing communities in NE Brazil. Journal of Ethnopharmacology 107:259-276.

Alves RRN, Rosa IL (2007a) Biodiversity, traditional medicine and public health: where do they meet? Journal of Ethnobiology and Ethnomedicine 3:14.

Alves RRN, Rosa IL (2007b) Zootherapeutic practices among fishing communities in North and Northeast Brazil: a comparison. Journal of Ethnopharmacology 111:82-103.

Alves RRN, Rosa IL, Santana GG (2007) The Role of Animal-derived Remedies as Complementary Medicine in Brazil. BioScience 57: 949-955.

Alves RRN, Barboza RRD, Silva Souto WMS (2010) A Global overview of canids used in traditional medicines. Biodiversity and Conservation 19:1513-1522.

Alves RRN, Léo Neto NA, Brooks SE, Albuquerque UP (2009) Commercialization of animal-derived remedies as complementary medicine in the semi-arid region of Northeastern Brazil. Journal of Ethnopharmacology 124:600-608.

Alves RRN, Oliveira MGG, Barboza RRD, Singh R, Lopez LCS (2011) AnimalBased Remedies as Complementary Medicines in the Semi-Arid Region of Northeastern Brazil. Evidence-Based Complementary and Alternative Medicine doi:10.1093/ecam/nep134.

Alves RRN, Santana GG, Rosa IL (2013) The Role of Animal-Derived Remedies as Complementary Medicine in Brazil. In: Alves RRN, Rosa IL (eds) Animals in traditional folk medicine: Implications for conservation. Springer Berlin Heidelberg, Berlin, pp. 289-301.

Alves RRN, Vieira WLS, Santana GG (2008) Reptiles used in traditional folk medicine: conservation implications. Biodiversity and Conservation 17:20372049.

Anderson EN, Pearsall DM, Hunn ES, Turner NJ (2011) Ethnobiology. Wiley Blackwell, USA

Apaza L, Godoy R, Wilkie D, Byron E, Huanca T, Leonard WR, Pérez E, ReyesGarcía V Vadez V (2003) Market and the use of wild animals for traditional medicine: a case study among the Tsinamé Amerindians of the Bolivian rain forest. Journal of Ethnobiology 23:47-64.

Arenas $P$ (1987) Medicine and magic among the Maka indians of the Paraguayan Chaco. Journal of Ethnopharmacology 21:279-295.

Arenas P (1995) Encuesta etnobotánica aplicada a indígenas del Gran Chaco. In: Braunstein J. (ed.) Hacia una nueva Carta Étnica del Gran Chaco 6. Centro del Hombre Antiguo Chaqueño, Las Lomitas, Formosa, Argentina, pp.161-178.

Arenas $P$ (1997) Las fuentes actuales y del pasado para la etnobotánica del Gran Chaco. Monografías Jardín Botánico de Córdoba. 5:17-25. 
Arenas $P(2000)$ Farmacopea y curación de enfermedades entre algunas etnias del Gran Chaco. In: A.G. Amat (Coord.) (ed) Farmacobotánica y Farmacognosia en Argentina (1980-1998). Ediciones Científicas Argentinas, La Plata, pp 87-118.

Arenas $P$ (2003) Etnografía y alimentación entre los Toba-Ñachilamole//ek y Wichí-Lhuku'tas del Chaco Central (Argentina). Del autor, Buenos Aires

Arenas $P$ (2009) Los estudios sobre medicina y farmacopea vernácula en el Gran Chaco. Rojasiana 8:81-100.

Arenas P, Braunstein JA (1981) Plantas y animales empleados en paquetes y otras formas de la magia amorosa entre los tobas taksik. Parodiana 1:149169.

Arenas P, Porini G (2009) Las aves en la vida de los tobas del oeste de la provincia de Formosa (Argentina). Tiempo de Historia, Paraguay.

Asta A (2006) Diseño de una estrategia regional de corredores de conservación en el Gran Chaco Argentina. Memorias del Taller de Resistencia, Chaco. Argentina. UICN - APN - Embajada Británica.

Bennett BC, Prance GT (2000) Introduced Plants in the Indigenous Pharmacopoeia of Northern South America. Economic Botany 54:90-102.

Benz B, Santana F, Pineda R, Cevallos J, Robles L, De Niz D (1994) Characterization of mestizo plant use in the Sierra de Manantlan, JaliscoColima, México. Journal of Ethnobiology 14:23-41.

Braunstein J (1983) Algunos rasgos de la organización social de los indígenas del Gran Chaco. Trabajos de Etnología. Publicación № 2. Universidad de Buenos Aires, Facultad de Filosofía y Letras, Instituto de Ciencias Antropológicas

Bourdy G, Chavez de Michel LR, Roca-Coulthard A (2004) Pharmacopoeia in a shamanistic society: the Izoceño-Guaraní (Bolivian Chaco). Journal of Ethnopharmacology 91:189-208.

Bucher EH (1980) Ecología de la fauna chaqueña. Una revisión. Ecosur 7:111159.

Bucher EH, Huszar PC (1999) Sustainable management of the Gran Chaco of South America: ecological promise and economic constraints. Journal Environmental Management 57:99-108.

Cabrera AL (1994) Regiones fitogeográficas argentinas. Enciclopedia Argentina de Agricultura y Jardinería. Tomo II (1) Acme, Buenos Aires.

Censabella M (2000) Las lenguas indígenas de la Argentina. Una mirada actual. EUDEBA, Buenos Aires.

CENSO (1981) Censo y estudio de la población indígena del Paraguay, 1981. Instituto Paraguayo del Indígena (IPA), Asunción.

Chan AAY-H (2012) Anthropomorphism as a conservation tool. Biodiversity and Conservation 21:1889-1892.

Chebez JC (2008a) Los que se van 1. Fauna Argentina amenazada. Problemática Ambiental. Anfibios y reptiles. Albatros, Buenos Aires. 
Chebez JC (2008b). Los que se van 2. Fauna Argentina amenazada. Aves. Albatros, Buenos Aires.

Chebez JC (2008c) Los que se van 3. Fauna Argentina amenazada. Mamíferos. Albatros, Buenos Aires.

Chebez JC (2009) Otros que se van. Fauna amenazada argentina. Albatros, Buenos Aires.

CITES (Convention on International Trade in Endangered Species of Wild Fauna and Flora) (2011) Appendices I, II and III. [http://www.cites.org/eng/resources/species.html]. Accessed June 2012

Cordeu EJ (1969/70) Aproximación al horizonte mítico de los Toba. Runa 12:67176.

Costa-Neto EM (1999) Healing with animals in Feira de Santana City, Bahia, Brazil. Journal of Ethnopharmacology 65:225-230.

Costa-Neto EM (2002) The use of insects in folk medicine in the State of Bahia, Northeastern Brazil, with notes on insects reported elsewhere in Brazilian folk medicine. Human Ecology 30:245-263.

Costa-Neto EM (2011) A zooterapia popular no Estado da Bahia: registro de novas espécies animais utilizadas como recursos medicinais. Ciência \& Saúde Coletiva 16(Supl. 1):1639-1650.

.Coutinho H, Vasconcellos A, Lima M, Almeida-Filho G, Alves RRN (2009) Termite usage associated with antibiotic therapy: enhancement of aminoglycoside antibiotic by natural products of Nasutitermes corniger (Motschulsky 1855). BMC Complementary and Alternative Medicine 9:35.

Cúneo P (2009) El sistema de género en toba con especial referencia al léxico etnozoológico y etnobotánico. Revista Estudios en Ciencias Humanas, Número 7. Facultad de Humanidades, Universidad Nacional del Nordeste, Argentina

Cúneo P, Porta A (2009) Vocabulario toba sobre peces y aves. In: Braunstein J, Messineo C (eds) Hacia una Nueva Carta Étnica del Gran Chaco. Las Lomitas, Formosa, pp $237-252$.

Dhar U, Rawal RS, Upreti J (2000) Setting priorities for conservation of medicinal plants - A case study in the Indian Himalaya. Biological Conservation 95:5765.

Di Lullo O (1944) El Folklore de Santiago del Estero. Medicina y Alimentación. Santiago del Estero, Argentina.

Dossey AT (2010) Insects and their chemical weaponry: New potential for drug discovery. Natural Product Reports 27:1737-1757.

ENDEPA (1986) Aborígenes en Argentina. Equipo Nacional de Pastoral Aborigen. Formosa, Argentina

Enriquez Vazquez P, Mariaca Mendez R, Retana Guiascon OG, Naranjo Pinera EJ (2006) Uso medicinal de la fauna silvestre en los altos de Chiapas, México. Interciencia 31:491-499. 
Ferreira FS, Brito SV, Saraiva RA, Araruna MKA, Menezes IRA, Costa JGM, Coutinhoc HDM, Almeida WO, Alves RRN (2010) Topical anti-inflammatory activity of body fat from the lizard Tupinambis merianae. Journal of Ethnopharmacology 130:514-520.

Filipov A (1997) La farmacopea natural en los sistemas terapéuticos de los indígenas pilagá. Parodiana 10:35-74.

Hecht AC, Martínez GJ, Cúneo P (2008) Infancia toba y mundo natural: De la atención del malestar físico a las pautas de socialización infantil. Acta Americana 16:81-106.

Heinrich M, Ankli A, Frei B, Weimann C, Sticher O (1998) Medicinal Plants in Mexico: Healers' consensus and cultural importance. Social Science and Medicine 47:1863-1875.

International Society of Ethnobiology Code of Ethics (2008) (with 2008 additions) [http://ise.arts.ubc.ca/global_coalition/ethics.php]. Accessed in February 2010

IUCN (International Union for Conservation of Nature and Natural Resources) (2011). IUCN Red List of threatened species.[ http://www.iucnredlist.org]. Accessed June 2012

Jacobo-Salcedo MR, Alonso-Castro AJ, Zarate-Martínez A (2010) Folk medicinal use of fauna in Mapimi, Durango, México. Journal of Ethnopharmacology 122:902-906.

Karlin U, Catalán L, Coirini R (1994) La naturaleza y el hombre en el Chaco Seco. Colección Nuestros Ecosistemas Proyecto GTZ. Proyecto Desarrollo Agroforestal en Comunidades rurales del Noroeste Argentino, Salta.

Le Breton D (1995) Antropología del cuerpo y modernidad. Nueva Visión, Buenos Aires.

Martin G (2000) Etnobotánica. Manual de Conservación. Serie "Pueblos y Plantas". WWF-UK. UNESCO y Royal Botanic Gardens, Kew, Reino Unido. Nordan Comunidad. Montevideo.

Martínez Crovetto R (1995) Zoonimia y etnozoología de los pilagá, toba, mocoví, mataco y vilela. Archivo de Lenguas Indoamericanas, Colección Nuestra América, Facultad de Filosofía y Letras, Buenos Aires.

Martínez GJ (2007) La farmacopea natural en la salud materno-infantil de los Tobas del Río Bermejito. Kurtziana 33(1):42-69 Volumen especial de etnobotánica.

Martínez GJ (2008) La farmacopea natural en la etnomedicina de los Tobas del Río Bermejito (Chaco, Argentina). Tesis Doctoral, Universidad Nacional de Córdoba, Argentina.

Martínez GJ (2010a) Los remedios naturales en la prevención y cuidado de la salud oral de los tobas del Chaco Central (Argentina). Boletín Latinoamericano y del Caribe de Plantas Medicinales y Aromáticas. BLACPMA 9:109-122.

Martínez GJ (2010b) Enfermedad y entidades anímicas del entorno natural: etiologías religioso-rituales y espacio-ambientales entre los tobas del - 
Chaco Central, Argentina. AlBR Revista de Antropología lberoamericana 5:189-221.

Martínez GJ (2010c) Los criterios terapéuticos en la farmacapea natural de los tobas Bermejeños del Chaco Central (Argentina). In: Pochettino, M.L., A.H. Ladio y P.M. Arenas (eds.) Tradiciones y transformaciones en etnobotánica, ed. Cyted, San Salvador de Jujuy, pp 213-218

Martínez GJ (2011) Pluralismo médico y etnomedicina entre los Tobas (Qom) del Río Bermejito (Chaco, Argentina). Desafíos y aportes para una gestión intercultural de la salud en el Impenetrable chaqueño. Revista del Museo de Antropología 4:195-210.

Martínez GJ, Planchuelo AM, Fuentes E, Ojeda MS (2006) A numeric index to establish conservation priorities for medicinal plants in the Paravachasca Valley, Córdoba, Argentina. Biodiversity and Conservation 15: 2457-2475.

Martínez GJ, Barboza GE (2010) Natural pharmacopoeia used in traditional Toba medicine for the treatment of parasitosis and skin disorders (Central Chaco, Argentina). Journal of Ethnopharmacology 132:86-100.

Medrano C, Maidana M, Gómez C (2011) Zoología Qom. Conocimientos tobas sobre el mundo animal. Ediciones Biológica. Serie Naturaleza, Conservación Sociedad № 3, Santa Fe, Argentina.

Miller ES (1979) Los tobas argentinos. Armonía y disonancia en una sociedad. Siglo XXI, México.

Monroy-Vilchis O, Cabrera L, Suárez P, Zarco-González MM, Rodrígeuz-Soto, Urios V (2008) Uso tradicional de vertebrados silvestres en la Sierra Nanchititla, México. Interciencia 33:308-313.

Morello J, Adámoli J (1974) Las Grandes Unidades de Vegetación y Ambiente del Chaco Argentino II. Vegetación y Ambiente de la Provincia del Chaco. INTA, Centro de Investigaciones de Recursos Naturales. Serie fitogeográfica 13. Coni, Buenos Aires.

Prado DE, 1993. What is the Gran Chaco vegetation in South America? I. A review. Contribution to the study of flora and vegetation of the Chaco. Candollea 48:145-172.

Red Agroforestal Chaco (1999) Estudio integral de la región del Parque Chaqueño. Ministerio de Desarrollo Social y Medio ambiente. Secretaría de Desarrollo Sustentable y Política Ambiental, Buenos Aires, Argentina.

Ringuelet R (1970) Panorama general de la fauna y de sus relaciones ecológicas del NE argentino y del dominio subtropical. Boletin de la Sociedad Argentina de Botánica, Suplemento 11:175-183.

Ruiz Moras E (2001) Ecosofía, etnohistoria y cosmología entre los toba taksek del Chaco Central. Scripta Ethnologica 23(1):201-229.

Schlage C, Mabula C, Mahunnah R, Heinrich M (2000) Medicinal plants of the Washambaa (Tanzania): Documentation and Ethnopharmacological Evaluation. Plant Biology 2:83-92.

Sistema de Información de Biodiversidad (2012) [ http://www.sib.gov.ar]. Accessed June 2012 
Terán B (1994) Lo que cuentan los tobas. Buenos Aires: Biblioteca de Cultura Popular.

Terán B (1998a) La división tripartita del cosmos entre los tobas orientales. Revista de la Escuela de Antropología 6:49-60.

Terán B (1998b) Unicidad y pluralidad: Una concepción de lo teofánico y potente en el mundo etnográfico chaqueño. Revista Casa Tomada № 8. Rosario. IOP Publishing PhysicsWeb [http//www.edicionesjuglaria.com.ar/seccionC/archivoscasatomada/terancasa8.ht $\mathrm{m}]$. Accessed december 2006

Terán B (2000) Los ámbitos geográficos conocidos por los tobas orientales y las nociones cosmovisionales vinculadas a los mismos. Revista Casa Tomada № 13. Rosario IOP Publishing Physics Web [http: //www.edicionesjuglaria.com.ar/seccionC/archivoscasatomada/terancasa13.htm]. Accessed december 2006

Terán L (2006) Animales shamánicos en la cosmovisión toba. Serie Animales de Importancia médica, ambiental y mítica. Yerba Buena, Colegio Pablo Apóstol, Tucumán.

Tola F (2001) Relaciones de poder y apropiación del "otro" en relatos sobre iniciaciones shamánicas en el Chaco Argentino. Journal de la Société des Américanistes 87:197-210.

Valles MS (2000) Técnicas cualitativas de investigación social. Reflexión metodológica y práctica profesional. Proyecto Editorial Síntesis sociología, España.

Vuoto LD (1999) Recolección animal entre los tobas de Formosa. In: Aschero C, Korstanje MA y Vuoto $\mathrm{P}$ (eds.) En los tres reinos: Prácticas de recolección en el Cono Sur de América. Instituto de Arqueología y Museo. Facultad de Ciencias Naturales e Instituto Miguel Lillo, Universidad Nacional de Tucumán, pp 253-260.

Wilbert J, Simoneau.K (1982) Folk literature of the toba Indians. Vol. One. UCLA Latin American Center Publications, Los Angeles, USA

Wright PG (1984) Quelques formes du chamanisme Toba. Bulletin de la Société Suisse des Américanistes 48:29-35.

Wright PG (2005) Cosmografías. Etnografías Contemporáneas 1(1):173-210.

Zacarías D (1993) Elementos naturales y su utilización en Pampa del Indio. In: Braunstein J (ed) Hacia Una Nueva Carta Étnica del Gran Chaco 5. Centro del Hombre antiguo Chaqueño, Las Lomitas, Formosa, pp 215-217.

Zak MR, Cabido M, Hodgson JG (2004) Do subtropical seasonal forests in the Gran Chaco, Argentina, have a future? Biological Conservation 120:589-598.

Zamudio F, Kujawska M, Hilgert $\mathrm{NI}$ (2010) Honey as medicinal and food resources. Comparison between Polish and multiethnic settlements of the Atlantic Forest, Misiones, Argentina. The Open Complementary Medicine Journal 2:58-73. 